


\section{Rapportage werkzaamheden kennissysteem Beheer-op-Maat 2018}

Tim Visser, Dick Melman, Igor Staritsky 
Visser, T., Th.C.P. Melman, en I. Staritsky, 2019. Rapportage werkzaamheden kennissysteem Beheerop-Maat 2018. Wageningen, Wageningen Environmental Research, Rapport 2927. 34 blz.; 1 fig.; 1 tab.; 47 ref.

Het kennissysteem voor Agrarisch Natuurbeheer, Beheer-op-Maat (BoM), is in 2018 op een aantal punten aangepast aan wensen van gebruikers (beheercollectieven). De belangrijkste inhoudelijke verbeteringen omvatten een verfijning van de bodemvochtigheidskaart, herziening van de weegwaarden voor de beheerpakketten o.b.v. literatuuronderzoek, uitbreiding van de experimenteermogelijkheden en toevoeging van een bodemkaart. De gebruikersvriendelijkheid van het systeem is verbeterd door laadschermen toe te voegen, de handleiding te ontsluiten en het proces van inloggen te vereenvoudigen. Daarnaast is veel voorbereidend werk verricht. Zo is een concept ontwikkeld voor een kentallenanalyse waarin de belangrijkste kentallen omtrent de effectiviteit van weidevogelbeheer overzichtelijk worden weergegeven - en is een samenwerking gestart met BoerenNatuur en LandschappenNL, met als doel de gegevensvoorziening te verbeteren.

De doorgevoerde verbeteringen hebben tot veel enthousiasme geleid. Mede daardoor is het aantal gebruikers fors toegenomen. Met de forse toename van het aantal gebruikers groeit de noodzaak om het kennissysteem te valideren. Daarnaast zijn er belangrijke opgaven voor het kennissysteem, waaronder het stimuleren van het gebruik voor lerend beheer en een uitbreiding naar andere leefgebiedtypen.

The knowledge system for Agricultural Nature Management, Management-to-Measure (BoM), has been adapted in a number of ways to the wishes of users (management collectives). The main improvements include a refinement of the soil moisture map, a revision of the weighing values for the management packages, expansion of the possibilities for experimenting and the addition of a soil map. The user-friendliness of the system has been improved by adding loading screens, opening up the manual and simplifying the login process. In addition, a lot of preparatory work has been done. For example, a concept has been developed for a knowledge analysis - in which the most important key figures on the effectiveness of meadow bird management are presented - and a collaboration has started with BoerenNatuur and LandscapesNL, with the aim of improving the data supply relating to management type and bird census.

The implemented improvements have led to a lot of enthusiasm. Partly because of this, the number of users has increased considerably. With the increase in the number of users, there is a growing need to validate the knowledge system. In addition, there are important tasks for the knowledge system, including encouraging use for learning management and an extension to other habitat types.

Trefwoorden: Beheer-op-Maat, Agrarisch natuurbeheer, collectieven, weidevogels, kennissysteem

Dit rapport is gratis te downloaden van https://doi.org/10.18174/468195 of op www.wur.nl/environmental-research (ga naar 'Wageningen Environmental Research' in de grijze balk onderaan). Wageningen Environmental Research verstrekt geen gedrukte exemplaren van rapporten.

2018 Wageningen Environmental Research (instituut binnen de rechtspersoon Stichting Wageningen Research), Postbus 47, 6700 AA Wageningen, T 03174807 00, www.wur.nl/environmental-research. Wageningen Environmental Research is onderdeel van Wageningen University \& Research.

- Overname, verveelvoudiging of openbaarmaking van deze uitgave is toegestaan mits met duidelijke bronvermelding.

- Overname, verveelvoudiging of openbaarmaking is niet toegestaan voor commerciële doeleinden en/of geldelijk gewin.

- Overname, verveelvoudiging of openbaarmaking is niet toegestaan voor die gedeelten van deze uitgave waarvan duidelijk is dat de auteursrechten liggen bij derden en/of zijn voorbehouden.

Wageningen Environmental Research aanvaardt geen aansprakelijkheid voor eventuele schade voortvloeiend uit het gebruik van de resultaten van dit onderzoek of de toepassing van de adviezen.

Wageningen Environmental Research Rapport 2927 | ISSN 1566-7197

Foto omslag: Werkplaats waarin collectieven aan de gang zijn gegaan met Beheer-op-Maat (foto: Imra Klein (HVHL)) 


\section{Inhoud}

$\begin{array}{ll}\text { Samenvatting } & \mathbf{5}\end{array}$

$\begin{array}{lll}1 & \text { Inleiding } & 7\end{array}$

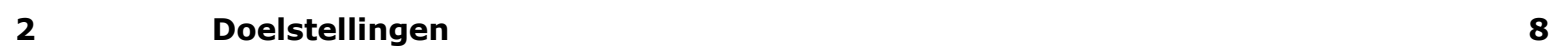

$\begin{array}{llr}3 & \text { Resultaten } & 11\end{array}$

3.1 Resultaten n.a.v. verbeterpunten 2017

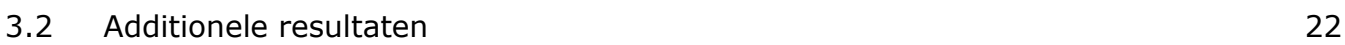

$4 \quad$ Discussie $r 25$

$5 \quad$ Conclusies en aanbevelingen $\quad 28$

$\begin{array}{ll}\text { Literatuur } & \mathbf{3 0}\end{array}$

$\begin{array}{ll}\text { Bijlagen } & 33\end{array}$ 



\title{
Samenvatting
}

\begin{abstract}
Wat is BoM?
Voor een effectief agrarisch natuurbeheer is goede ontsluiting van kennis cruciaal. Door het toegankelijk maken en delen van kennis over soorten, gebieden en beheermaatregelen kan het lerend beheer vorm krijgen en verder worden ontwikkeld. De afgelopen jaren is gewerkt aan het kennissysteem voor agrarisch natuurbeheer Beheer-op-Maat (BoM).

Beheer-op-Maat is een kennissysteem waarin wetenschappelijke kennis met betrekking tot de effectiviteit van weidevogelbeheer op een laagdrempelige manier wordt ontsloten. Op de website van Beheer-op-Maat kunnen de gebruikers (tot nu toe vooral collectieven) analyses uitvoeren voor eigen werkgebied. Beheer-op-Maat geeft o.a. inzicht in de landschappelijke kwaliteit van het werkgebied, de effectiviteit van het beheer en de vraag of er voldoende geschikt habitat aanwezig is om te komen tot een duurzame populatie. Met behulp van Beheer-op-Maat kunnen de gebruikers werken aan planoptimalisatie.
\end{abstract}

\section{Resultaten 2018}

De bevindingen en suggesties van de gebruikers van het kennissysteem vormen de basis voor de ontwikkeling van Beheer-op-Maat. Om verbeterwensen in beeld te krijgen - en om de collectieven te ondersteunen bij het gebruik van Beheer-op-Maat- zijn in vervolg op 2017 ook dit jaar een aantal werkplaatsen georganiseerd door BoerenNatuur en Hogeschool Van Hall Larenstein. Deze werkplaatsen zijn door negentien collectieven bezocht. De collectieven waren positief-kritisch over de mogelijke betekenis van BoM voor de beheerpraktijk.

Beheer-op-Maat is afgelopen jaar op een aantal punten aangepast aan wensen van gebruikers (beheercollectieven). De belangrijkste inhoudelijke verbeteringen omvatten een verfijning van de bodemvochtigheidskaart, herziening van de weegwaarden voor de beheerpakketten o.b.v. literatuuronderzoek, uitbreiding van de experimenteermogelijkheden en toevoeging van een bodemkaart. De gebruikersvriendelijkheid van het systeem is verbeterd door laadschermen ${ }^{1}$ toe te voegen, de handleiding te ontsluiten en het proces van inloggen te vereenvoudigen. Daarnaast is veel voorbereidend werk verricht. Zo is een concept ontwikkeld voor een kentallenanalyse - waarin de belangrijkste kentallen omtrent de effectiviteit van weidevogelbeheer overzichtelijk worden weergegeven - en is een samenwerking gestart met BoerenNatuur en LandschappenNL, met als doel de gegevensvoorziening te verbeteren.

\section{Toename in gebruik}

Bovengenoemde verbeteringen zijn doorgevoerd op basis van suggesties die tijdens contactmomenten met de gebruikersgroep zijn aangedragen. Mede daardoor zijn de verbeteringen met veel enthousiasme ontvangen. Dit heeft geleid tot een forse toename van het aantal gebruikers van Beheer-op-Maat; het merendeel van de collectieven in weidevogelgebieden maakt meer of minder gebruik van BoM. Daarnaast is duidelijk geworden dat het gebruik van Beheer-op-Maat sterk afhankelijk is van de gevoelde urgentie om het kennissysteem te gebruiken. Naar aanleiding van de naderende optimalisatieronde van de beheerplannen, de werkplaatsen en de nieuwsbrief nam het gebruik sterk toe.

\section{Hoe nu verder?}

- Oprichten gebruikersgroep. Het afgelopen jaar is duidelijk geworden dat verbeteringen aan het kennissysteem naar aanleiding van verbeterwensen van gebruikers tot veel enthousiasme leiden. Om verbeterwensen in de toekomst op een meer systematische manier in beeld te krijgen, lijkt het raadzaam om een gebruikersgroep samen te stellen die met enige regelmaat bijeenkomt om de ontwikkeling van het kennissysteem te bespreken. De verbeterwensen die binnen deze gebruikersgroep naar voren komen, zouden sturend kunnen zijn voor doorontwikkeling van het kennissysteem.

\footnotetext{
${ }^{1}$ Pop-upscherm dat verschijnt tijdens het vergaren van informatie voor de berekeningen. Hiermee ziet de gebruiker tijdens het wachten dat het systeem actief is.
} 
- Technisch-inhoudelijke helpdesk instellen. Het afgelopen jaar is een helpdesk opgericht waar gebruikers van Beheer-op-Maat terecht kunnen met vragen. Van deze helpdesk is veelvuldig gebruikgemaakt (vragen vanuit zeven collectieven en diverse andere organisaties). Er is zowel geholpen bij het inladen van gegevens als bij het interpreteren van de resultaten. Gezien de optimalisatieronde die in juni 2019 zijn beslag zal krijgen, lijkt het verstandig om een dergelijke helpdesk nogmaals beschikbaar te stellen, zodat hulp kan worden geboden bij het gebruik van Beheer-op-Maat.

- Ontsluiting gegevens. De beperkte beschikbaarheid van beheer- en territoriagegevens staat het gebruik van Beheer-op-Maat soms in de weg. Het is raadzaam om de samenwerking met gegevensbeherende organisaties zoals LandschappenNL en BoerenNatuur verder te ontwikkelen, zodat Beheer-op-Maat met regelmaat wordt gevoed met up-to-date gegevens.

- Valideren \& kalibreren. Met de forse toename in het gebruik groeit de urgentie om de uitkomsten van het model te valideren: wat is de nauwkeurigheid en de betrouwbaarheid van de uitkomsten; in welke omstandigheden gelden ze? Validatie van het kennissysteem zal tevens de mogelijkheid bieden om de rekenregels en -waarden te kalibreren.

- Inhoudelijk doorontwikkelen. Het model kan inhoudelijk verder worden ontwikkeld. Het afgelopen jaar is duidelijk geworden dat er veel interesse is in de kentallenanalyse. Het zou raadzaam zijn om het mogelijk te maken deze analyse met één druk op de knop uit te kunnen voeren voor een werkgebied naar keuze. Verder liggen er mogelijkheden om de rekenregels te verfijnen aan de hand van nieuwe wetenschappelijke inzichten en/of naar aanleiding van de validatie/kalibratie van het kennissysteem.

- Lerend beheer. De werkplaatsen hebben laten zien dat BoM in beginsel een waardevolle tool kan zijn voor lerend beheer. Nu zijn de werkplaatsen in 2017 en 2018 een min of meer incidenteel gebeuren geweest; voor lerend beheer zouden dergelijke sessies regelmatig moeten plaatsvinden. In welke vorm dat zou moeten en met welke urgentie, is een punt van nadere overweging. Het zou goed zijn als, naast collectieven, ook terreinbeheerders, onderzoekers en beleidsmakers deel zouden nemen. Daarmee komt er een meer gedeeld beeld over wat er nodig en mogelijk is om tot een effectief weidevogelbeheer te komen. Wellicht vormt de te ontwikkelen kentallenanalyse een aanknopingspunt om in 2019 een bijeenkomst te organiseren die zich voornamelijk richt op lerend beheren.

- Uitbreiden leefgebiedtypen. Op meerdere fronten wordt gevraagd naar verbreding van BoM naar de overige leefgebiedtypen (droge dooradering, natte dooradering, open akkers). Het gaat hier niet alleen om collectieven die zich voornamelijk richten op andere doelsoorten dan weidevogels, maar ook om het PBL, om beleidsadviezen te kunnen geven, zowel wat betreft potenties voor natuur buiten NNN als wat betreft de te verwachten effecten van agrarisch natuurbeheer. Het is duidelijk dat veel werk zal moeten worden verricht om BoM operationeel te maken voor deze leefgebiedtypen. Het is belangrijk om hierbij alle kansen te grijpen en om inspanningen op dit front zo veel mogelijk te bundelen. 


\section{$1 \quad$ Inleiding}

Voor een effectief agrarisch natuurbeheer is goede ontsluiting van kennis cruciaal. Door het toegankelijk maken en delen van kennis over soorten, gebieden, beheermaatregelen kan het lerend beheer vorm krijgen en verder ontwikkeld worden. In voorgaande jaren is er gewerkt aan het kennissysteem agrarisch natuurbeheer Beheer-op-Maat (BoM). Dat ontsluit beschikbare, ecologisch relevante informatie op een voor beheerders laagdrempelige wijze. Het accent ligt tot nog toe op het weidevogelbeheer.

Waar het weidevogels betreft, is BoM inhoudelijk al redelijk ver ontwikkeld. Het is belangrijk om te weten of het voor de praktijk van de collectieven ook kan werken. Essentieel bij het verder ontwikkelen van BoM is zicht te hebben op de ervaringen van de gebruikers en hun (verbeter)wensen. Daartoe is samenwerking gezocht met BoerenNatuur (BN) en Hogeschool Van Hall Larenstein (HVHL). Daar bleek belangstelling voor te zijn. De ex-ante-evaluatie ANLb-2016, waarin de beheerplannen van de collectieven op ligging, ruimtelijke samenhang en kwaliteit zijn geëvalueerd (Melman et al., 2016), was voor de collectieven aanleiding om de inzet van het beheer te verbeteren.

Door HVHL en BNL is het initiatief genomen om een aantal werkplaatsen te organiseren gericht op de verbetering van de weidevogelbeheerplannen. Daarbij wilden ze graag gebruikmaken van BoM. Dat paste precies bij de scope van onderhavig project. In deze werkplaatsen stond lerend beheren centraal en ze hadden tevens tot doel bij te dragen aan het werken aan één taal en begrippenset voor het weidevogelbeheer, waaraan door alle betrokkenen een groot belang wordt toegekend. De bijeenkomsten leverden inzicht in de toegankelijkheid en bruikbaarheid van BoM en boden tevens de gelegenheid om verbeterwensen te inventariseren (Manhoudt et al., 2018).

De opbrengst van de werkplaatsen in 2017 en 2018 was de voeding voor de werkzaamheden zoals die in onderhavig project zijn opgepakt en uitgevoerd.

Het kennissysteem agrarisch natuurbeheer in het kort

(voor een overzicht van de rapportages, zie literatuur)

Het kennissysteem ontsluit ecologische kennis voor de leefgebiedtypen die in het ANB relevant zijn. Het is opgenomen in een GIS. Het omvat:

- kennisregels voor bepaling basis habitatkwaliteit (geïntegreerde beoordeling van diverse habitatfactoren);

- kennisregels voor bepaling gerealiseerde habitatkwaliteit door beheer (geïntegreerde beoordeling basis habitatkwaliteit + beheerregime);

- indicatoren voor succesvolle territoria (geïntegreerde beoordeling gerealiseerde habitatkwaliteit en aanwezige territoria);

- koppelingsmogelijkheden met externe bronnen voor beheer (bijv. RVO-bestanden) en soortverspreidingskaarten (bijvoorbeeld SOVON, De Landschappen);

- mogelijkheden voor toevoegen van eigen gegevens over beheer en voorkomen van soorten;

- kansrijkdomkaarten (gebaseerd op verspreiding soorten en gebiedseigenschappen) [alsmede kaarten van de begrensde gebieden, zodat zichtbaar is waar van spanning tussen beide sprake is];

- soorten fiches (identiek aan die van www.portaalnatuurenlandschap).

PM (wel conceptueel ontwikkeld, nog niet in het systeem opgenomen)

- indicatoren voor ruimtelijke concentratie van beheer per leefgebiedtype;

- indicatoren voor ruimtelijke samenhang tussen beheer verschillende leefgebiedtypen.

Het kennissysteem kan gebieden karakteriseren in de vorm van kentallen, onder andere: omvang, basishabitatkwaliteit, areaal verschillende beheervormen, gerealiseerde habitatkwaliteit, dichtheid territoria, door beheer veiliggestelde territoria etc.

Het kennissysteem is online ontsloten en biedt voor collectieven de mogelijkheid om bovenstaande zaken voor het eigen gebied uit te zoeken. 


\section{Doelstellingen}

Het kennissysteem Beheer-op-Maat heeft als doel alle beschikbare wetenschappelijke kennis omtrent weidevogelbeheer te vertalen naar kaartbeelden en figuren die eenvoudig te interpreteren zijn. Binnen Beheer-op-Maat kan de gebruiker analyses uitvoeren voor eigen werkgebied (o.a. landschappelijke kwaliteit, ligging en effectiviteit van het beheer). De uitkomsten van de analyses vormen vervolgens input voor planverbetering. Het uiteindelijke doel is dat BoM een betrouwbaar en erkend hulpmiddel is om de ecologische effectiviteit van het beheer te vergroten.

Achterliggend doel van dit project is de bruikbaarheid van het kennissysteem voor lerend beheer in het agrarisch natuurbeheer te vergroten. De door HVHL georganiseerde werkplaatsen (zowel in 2017 als 2018) boden daarvoor belangrijke input, als bron van gebruikerservaringen en verbeterwensen. De doelstellingen voor 2018 zijn in eerste instantie gebaseerd op de verbeterpunten die zijn vergaard tijdens de werkplaatsen in 2017. De belangrijkste van deze aangedragen punten waar in dit project aan is gewerkt, zijn:

1. Plan maken voor aansluiting op SCAN-GIS en andere externe gegevensbronnen

- Voor gebruikers is het belangrijk dat gegevens uit andere bronnen geautomatiseerd worden ontsloten. Dat betreft gegevens over het beheer en gegevens over het voorkomen van weidevogels.

\section{Langjarig plan van aanpak: toepassing Beheer-op-Maat voor natte en droge dooradering} en akkers

- Vanuit collectieven is er naast weidevogels ook behoefte aan kennisontsluiting voor de andere leefgebiedtypen, zoals open akkers en droge dooradering. Voor deze leefgebiedtypen is een plan van aanpak gewenst.

\section{Kentallen}

- In het kader van het toegroeien naar één taal en begrippenset voor het weidevogelbeheer is het gewenst om kentallen te ontwikkelen die de essentie van de gebiedseigenschappen, de inspanningen t.a.v. inrichting en beheer en de weidevogelkwaliteiten weergeven. De volgende elementen zijn hierin van belang:

- identificeren van essentiële kentallen voor collectieven/beheerders;

- vaststellen welke data benodigd zijn om deze kentallen te berekenen;

- geautomatiseerde berekening van de kentallen en de weergave hiervan in figuren.

\section{Gebruiksvriendelijkheid}

- Om drempels voor het gebruik van BoM te effenen, is voortdurende aandacht voor de gebruikersvriendelijkheid essentieel. Gebaseerd op de wensen van de collectieven zijn de volgende aspecten geselecteerd om aan te pakken:

- Laad-icoon toevoegen, waardoor duidelijk wordt hoe lang het nog duurt voordat een analyse is uitgevoerd.

- Inloggen en selecteren van gegevens en gebied vereenvoudigen (permissies om gegevens in te zien koppelen aan accounts (ieder collectief een eigen account)).

- Beknopte handleiding aanbieden.

- Mogelijk maken om kaartbeelden van analyses op te slaan als jpg/pdf (met bijbehorende legenda).

- Helpdesk oprichten.

\section{Transparantie/inzichtelijkheid}

- Bij het krijgen van vertrouwen in BoM is het belangrijk dat gebruikers inzage hebben in de wijze waarop een en ander wordt berekend, zo is gebleken bij de BoM-werkplaatsen. Hierin kan worden voorzien door: 
- inzicht te bieden in totstandkoming resultaten (algoritmes);

- verwijzingen naar rapportages toevoegen waarin wordt beschreven hoe het kennissysteem is ontwikkeld en op welke onderzoeken/expert judgements de berekeningen berusten.

\section{Aansluiting terminologie BoM met de regeling}

- Omwille van de herkenbaarheid voor gebruikers is het van belang in de terminologie zo veel mogelijk aan te sluiten bij de termen zoals die in de regeling van de ANLb wordt gehanteerd. Veranderingen in de terminologie van de regeling dienen waar mogelijk doorgevoerd te worden in BoM.

\section{Experimenteermogelijkheden}

- Bij het maken van nieuwe beheerplannen hebben collectieven behoefte om te experimenteren met het te verwachten effect van bepaalde maatregelen die zij overwegen. Bijvoorbeeld: hoe werkt het verwijderen van bosjes uit op de habitatgeschiktheid; wat is het verwachte effect van een uitgestelde maaiweidedatum? etc. Om hier gevoel bij te krijgen, is het kunnen 'spelen' met maatregelen belangrijk. Een dergelijke mogelijkheid ontstaat door:

- het mogelijk maken om conceptbeheerplannen te analyseren (uploaden conceptplannen als shapefile, of handmatig invoeren);

- het mogelijk maken om basisfactoren fictief te optimaliseren (wat zou het opleveren als we het gebied vernatten? Als we verstorende elementen verwijderen?).

\section{Validatie}

- Naarmate BoM meer gebruikt wordt bij planvorming en planevaluatie groeit de behoefte om onafhankelijk inzicht te verkrijgen in hoe nauwkeurig en betrouwbaar de inzichten zijn die met BoM worden verkregen. Dit kan door middel van validatie. Hierin wordt de feitelijke ruimtelijke spreiding van weidevogelgezinnen gerelateerd aan de middels BoM berekende habitatkwaliteit.

- Op voorhand is duidelijk dat onderhavig project geen ruimte biedt voor validatie. Wel kan een onderzoeksopzet daartoe worden uitgewerkt.

\section{Contact/communicatie OG, projectomgeving}

- In de loop van de tijd is BoM bij de eerste kring van betrokkenen redelijk bekend geworden. Sterke en zwakke punten zijn min of meer herkend en onderkend. Omdat de omgeving waarin BoM fungeert voortdurend evolueert en in BoM gestaag gebruikerswensen worden geïncorporeerd, is het belangrijk om met (potentiële) gebruikers contact te houden. Daarmee wordt een actueel beeld verkregen hoe BoM fungeert en hoe dit kan worden verbeterd.

\section{Bijkomende doelstellingen}

Naast bovenstaande geprioriteerde doelstellingen is tijdens de werkplaatsen van 2018 een aantal verbeterpunten aan het licht gekomen, die vanwege de urgentie zijn toegevoegd aan de doelstellingen voor 2018. Het gaat hierbij om de volgende zaken.

\section{Toevoegen bodemkaart}

Een aantal collectieven wil graag inzicht in de samenstelling van de bodem, voornamelijk om te gebruiken als onderbouwing bij het kiezen van de juiste locaties voor beheermaatregelen (plas-dras, kruidenrijk gras) waarvan de effectiviteit samenhangt met het bodemtype.

\section{Verbeteren kaart Bodemvochtigheid}

Tijdens de werkplaatsen is meerdere malen opgemerkt dat de droogleggingskaart plaatselijk afwijkt van de feitelijke situatie in het veld. Hier liggen naar alle waarschijnlijkheid meerdere factoren aan ten grondslag:

- De droogleggingskaart is verouderd: het waterpeil is plaatselijk gewijzigd.

- Binnen de rekenwijze in BoM wordt nog geen rekening gehouden met kwel (die plaatselijk de bodemvochtigheid kan verbeteren) en bodemtype (de klassegrenzen zouden moeten worden gedifferentieerd per bodemtype: een kleibodem tolereert een grotere drooglegging dan een veenbodem). 
Het doel is om in 2018 te komen tot een vernieuwde droogleggingskaart, waarbij wordt gerekend met de recentste peilbesluiten en waarbij het bodemtype en de kweldruk in het berekenen van de bodemvochtigheid worden meegenomen.

\section{Artefacten oplossen}

Tijdens de werkplaatsen is aan het licht gekomen dat plas-dras nog niet de plaatselijke drooglegging verbetert in de berekening van de habitatkwaliteit. Daarnaast wordt in BoM niet altijd de laatst berekende gerealiseerde kwaliteit weergegeven. Beide zaken dienen in 2018 te worden opgelost en vereisen een aantal aanpassingen in de code.

\section{Rekenwaarden beheerpakketten herzien o.b.v. literatuuronderzoek}

De afgelopen jaren is veel relevante literatuur uitgekomen. De weegwaarden van de beheerpakketten zijn toe aan vernieuwing op basis van de resultaten van dit onderzoek.

\section{Toevoegen Q35-kaarten}

Voor het uitbreiden van het kennissysteem naar de leefgebieden akker, droge en natte dooradering (doelstelling 2) is veel literatuur nodig. Als eerste stap is het relevant om inzicht te krijgen in het voorkomen van de doelsoorten. Daarmee kan duidelijk worden welke gebieden de hoogste dichtheden aan doelsoorten herbergen. Hiertoe dienen Q35-kaarten te worden gemaakt van de doelsoorten uit de genoemde leefgebiedtypen (Q35-kaarten worden gemaakt door het kleinst mogelijke areaal te selecteren waarbinnen $35 \%$ van de landelijke populatie van een specifieke soort voorkomt. Anders gezegd: de gebieden waar de soort in kwestie in de hoogste dichtheden voorkomt (35\% van de landelijke populatie)).

\section{Weidevogelvakken beschikbaar maken}

Tijdens de werkplaatsen is door de deelnemers meerdere malen gevraagd om meer deelgebieden en bijbehorende beheer- en weidevogelgegevens beschikbaar te maken. Het handmatig intekenen van deelgebieden is onbegonnen werk en leidt veelal tot irrelevante gebiedsgrenzen vanuit het oogpunt van de weidevogels. Een oplossing is om de grenzen van weidevogelvakken te gebruiken als deelgebieden.

Een weidevogelvak is een gebied dat voor weidevogelgezinnen als een ruimtelijke eenheid fungeert, omdat het gebied wordt omgrensd door onneembare barrières voor weidevogelgezinnen, zoals snelwegen, steden en brede watergangen. In andere woorden: weidevogelgezinnen zitten tijdens het broedseizoen 'opgesloten' in weidevogelvakken. Juist om deze reden is het zeer relevant de effectiviteit van het weidevogelbeheer te analyseren op het niveau van weidevogelvakken: de aanwezige weidevogelgezinnen moeten hun jongen zien groot te brengen in het foerageerhabitat dat beschikbaar is binnen de grenzen van het weidevogelvak.

Het doel is om op korte termijn te verkennen hoe deze weidevogelvakken kunnen worden gemaakt en of het mogelijk is om deze voor 2019 te operationaliseren. 


\subsection{Resultaten n.a.v. verbeterpunten 2017}

\section{Plan maken voor aansluiting op SCAN-GIS en andere externe gegevensbronnen}

Het kennissysteem Beheer-op-Maat valt of staat bij de beschikbaarheid van actuele beheer-en territoriagegevens. Tot voor kort werden deze gegevens aangeleverd door de collectieven en handmatig ingelezen in het kennissysteem. Dit was erg tijdrovend en zorgde voor complicaties. Dit omdat de beheer- en territoriagegevens in de regel niet eenvormig worden aangeleverd en veel artefacten bevatten (dubbele territoria, typefouten etc.).

Om deze reden heeft op 19 juni een overleg plaatsgevonden met BoerenNatuur (Inger Wilms). BoerenNatuur is beheerder van het SCAN-GIS-portaal, dat door collectieven wordt gebruikt om beheergegevens in te zien. Hierdoor beschikt BoerenNatuur over alle benodigde beheergegevens. In het gesprek is duidelijk geworden dat BoerenNatuur bereid is de aansluiting van BoM op SCAN-GIS mogelijk te maken, zeker gezien de forse toename in het aantal gebruikers. BoerenNatuur heeft aangegeven dat zij wil faciliteren bij het aanleveren van beheergegevens. Daarbij werd vermeld dat de gegevens - in verband met de nieuwe Europese privacywetgeving - uitsluitend mogen worden afgegeven in samenspraak met de betreffende collectieven. Hiertoe is sinds juni 2018 een bericht geplaatst op het intranet van SCAN-GIS, met het verzoek toestemming af te geven als men aan de slag wil met Beheer-op-Maat. Het doel is om dit verder te verkennen: welke mogelijkheden zijn er om de ontsluiting van gegevens volledig automatisch te laten verlopen? Met welke frequentie is dit mogelijk? etc.

Wat betreft de territoriagegevens heeft BoerenNatuur aangegeven geen eigenaar van de gegevens te zijn. De gegevens zijn doorgaans in eigendom van de collectieven, de vrijwilligers en/of LandschappenNL. Boerennatuur is wel bereid te bemiddelen om de gegevens voor gebruik in BoM te bevorderen.

In een overleg met de provinciale coördinatoren agrarisch natuurbeheer van LandschappenNL (september 2018) is een vraag gesteld over samenwerking in de vorm van ter beschikking stelling van gegevens over telgebieden en het voorkomen van weidevogels enerzijds en het gebruik van BoM anderzijds. Essentieel voor dit overleg was de vraag te zien als een tweezijdige samenwerking en niet om eenzijdige gegevensverstrekking. Aan de hand van een presentatie van BoM ontspon zich een levendige, constructieve discussie of en hoe BoM als hulpmiddel voor planvorming en -evaluatie kan worden gebruikt. Belangrijke elementen daarin zijn actualiteit en nauwkeurigheid van de basisgegevens, de verantwoordelijkheid voor borging en het type gebruik van de met BoM verkregen inzichten. De in BoM uitgewerkte benadering wordt breed ondersteund, waarbij de volgende punten als zeer belangrijk werden genoemd. Het kennissysteem is en blijft een hulpmiddel. Het reflecteert de kennis die er is, toegepast in een specifiek gebied. De gebruiker zal altijd moeten nagaan of deze inzichten hem helpen en daar zijn voordeel mee kunnen doen bij de planvorming, bij de communicatie in het gebied zelf en bij uitwisseling van ervaringen met andere collectieven.

Vanuit deze achtergrond is men positief over samenwerking en wil daarin ook bijdragen in de vorm van het inzetten van eigen gegevens. Hierover zal nog wel met de achterbannen worden overlegd. Tegelijkertijd wil men ruimte krijgen om eigen analyses met BoM te kunnen doen die nu nog niet mogelijk zijn. Vanuit WENR is aangegeven dat dat laatste zeker de bedoeling is (graag zelfs); dit illustreert het wederzijdse karakter van de samenwerking.

\section{Meerjarig plan van aanpak: toepassing Beheer-op-Maat voor natte en droge dooradering en akkers}

In toenemende mate is aandacht voor de andere leefgebiedtypen binnen het agrarisch natuurbeheer: natte dooradering, droge dooradering en akkers. Hiermee groeit het belang om Beheer-op-Maat ook voor deze leefgebiedtypen beschikbaar te maken. 
Een hinderpaal bij het optuigen van een kennissysteem voor deze leefgebieden is de beperkte beschikbaarheid van voor dit doel bruikbare wetenschappelijke literatuur. Voor weidevogels is een groot deel van de habitateisen (maximale drooglegging, verstoringsafstand van opgaande structuren, minimaal vereist areaal foerageerhabitat etc.) gekwantificeerd. Dit is voor de soorten die in de overige leefgebiedtypen voorkomen in veel beperktere mate het geval. Wetenschappelijke literatuur is voor slechts een klein aantal soorten beschikbaar (patrijs, veldleeuwerik, grauwe kiekendief). De informatie in de literatuur die voor de overige soorten beschikbaar is, is voor ons doel incompleet en/of alleen beschrijvend en niet kwantitatief van aard. In 2018 is door Teunissen (et al.) een poging gedaan om te ontrafelen welke landschappelijke factoren op landelijk niveau de verspreiding van vogels voor akkers en droge dooradering verklaren. De resultaten van dit onderzoek zijn moeilijk te vertalen naar voor een kennissysteem bruikbare weeg- en rekenwaarden. Landschappelijke configuratie bleek als factor op landelijk niveau niet eenduidig operationeel gedefinieerd te kunnen worden. Gegevens over grondgebruik en gebruik van bestrijdingsmiddelen waren ruimtelijk weinig gedetailleerd beschikbaar. Voor de leefgebiedtypen natte dooradering is eveneens weinig wetenschappelijke literatuur beschikbaar, met name als het gaat om de effectiviteit van beheermaatregelen.

De beperkte beschikbaarheid aan wetenschappelijke literatuur maakt het niet mogelijk om op korte termijn voor andere leefgebiedtypen een kennissysteem op te tuigen met een vergelijkbaar detailniveau als het huidige BoM. Dit leidt tot een zoektocht naar een aanpak die minder hoge eisen stelt op het vlak van de beschikbaarheid van wetenschappelijke literatuur. Vorig jaar is een model (MNP-NC) ontwikkeld om de bijdrage van zogenaamde natuurcombinaties onderbouwd in beeld te brengen, toegespitst op VHR-soorten (zie Melman et al., 2017a: WOt-technical report 107). Het doel van de modellering was om voor beleidsevaluaties (ex post, ex ante) een globaal beeld te krijgen wat de natuurpotenties van natuurcombinaties zijn. De gehanteerde methodiek in dit project is relatief eenvoudig, aangezien de methodiek op dusdanige wijze is opgetuigd dat op landelijke schaal globale uitspraken kunnen worden gedaan. Wellicht kan deze methodiek worden gebruikt als basis voor de uitbreiding van Beheer-op-Maat naar de leefgebieden akkers, droge en natte dooradering.

Bovenstaande overwegingen hebben geresulteerd in een stappenplan voor het uitbreiden van BoM naar andere leefgebiedtypen (zie onderstaand tekstkader). 
Stappenplan uitbreiden Beheer-op-Maat naar andere leefgebiedtypen

Stap 1: Bepalen of uitspraken moeten worden gedaan op soort- of soortgroepsniveau:

- Wat is de noodzaak van uitspraken op soortniveau? Wat gaat verloren wanneer wordt gekozen voor uitspraken op groepsniveau?

- Voor welke soorten in de drie leefgebiedtypen is voldoende literatuur beschikbaar om uitspraken te doen op soortniveau?

- Is het mogelijk om soorten op basis van ecologische karakteristieken te groeperen? Welke karakteristieken komen hiervoor in aanmerking? Is er voldoende overlap in habitateisen? Kunnen soorten in meerdere soortgroepen voorkomen?

- Is het zinnig om een soortgroep te modelleren aan de hand van een gidssoort? Zo ja, wat zijn de gevolgen voor de betrouwbaarheid en nauwkeurigheid van de uitspraken over de groep als geheel?

- Op basis van de antwoorden op bovenstaande vragen een keuze maken: verder gaan op soort- of groepsniveau of voorlopig geen van beide afschrijven?

Stap 2: Verzamelen van relevante informatie t.b.v. modellering (op soort en/of groepsniveau) voor een kleine selectie aan soorten en/of soortgroepen:

- Raadplegen soortenfiches ANLB

- Raadplegen wetenschappelijke literatuur

- Raadplegen soortenfiches Natuurcombinaties (zie Melman et al., 2017a)

Stap 3: Vertalen van verzamelde informatie naar voor een model bruikbare reken- en weegwaarden voor soorten/soortgroepen

Stap 4: Proefdraaien van modellen voor selectie aan soorten/soortgroepen

Stap 5: Evalueren uitkomsten van stap 4:

- Wat is de geloofwaardigheid (betrouwbaarheid en nauwkeurigheid) van de resultaten?

- Is de aanpak werkbaar (voldoende snel, voor beheer bruikbare resultaten (in planning evaluatie)?

- Welke aanpassingen zouden nodig zijn om de resultaten van het model te verbeteren?

Stap 6: Aanmaken van een webtool waarin kaarten kunnen worden geraadpleegd en analyses kunnen worden uitgevoerd per deelgebied.

De realisatie van de hierboven benoemde stappen vergt een traject dat meerdere jaren in beslag zal nemen. Om draagvlak te verkrijgen, zullen de collectieven/beheerders erbij betrokken dienen te worden (in de vorm van een gebruikersgroep). Wellicht zal het geheel iteratief moeten worden aangepakt: snel werken naar voorlopig werkbare versies en bij de verbetering ervan gebruikmaken van de opmerkingen van de gebruikers.

\section{Ontwikkelen van kentallen}

Kentallen geven de belangrijkste informatie omtrent weidevogelbeheer op een kernachtige en overzichtelijke wijze weer (in figuren en tabellen) voor een bepaald (deel)gebied. De kentallen hebben betrekking op gebiedseigenschappen, beheerinspanningen en aantallen/dichtheden van de weidevogels. De kentallen kunnen helpen bij het analyseren van gebiedseigenschappen en de effectiviteit van het gevoerde weidevogelbeheer en kunnen een belangrijke rol innemen binnen het proces van planoptimalisatie. Ze maken het ook mogelijk om gebieden onderling te vergelijken (benchmark) en geven een houvast om van elkaar te leren. Tijdens de werkplaatsen in januari 2018 is in overleg met de collectieven verkend welke kentallen onderdeel zouden moeten zijn van een dergelijke analyse. Met de geleverde input is gekomen tot onderstaand resultaat (zie figuur 1). Met behulp van de kentallenanalyse verkrijgt de beheerder/het collectief inzicht in:

$\underline{1 .}_{\text {Beheer }^{2}}$ : aantal hectare per beheerpakket, binnen geselecteerd deelgebied, op basis van recentst aangeleverde beheermozaïek.

2. Weidevogels: aantallen, dichtheid en BTS: ontwikkelingen weidevogelpopulatie per soort (aantallen, dichtheden en bruto territoriaal succes). Maak gebruik van de selectieknop 'Jaar' om te kiezen voor een specifiek broedseizoen of voor het langjarig gemiddelde.

3. Potentiële kwaliteit: de potentiële kwaliteit is de combinatie van drooglegging, openheid, verstoring en de voedselrijkdom van de bodem. In het geval dat alle vier de factoren op orde zijn, wordt een hoge potentiële kwaliteit toegeschreven aan de locatie in kwestie. Wanneer een of meerdere factoren

\footnotetext{
2 De nummering van de kentallen komt terug in de nummers van de onderdelen van figuur 1.
} 
niet optimaal zijn, neemt de potentiële kwaliteit van de locatie af. Binnen dit cirkeldiagram is weergegeven hoeveel hectare van het deelgebied behoort tot de vier kwaliteitscategorieën. Met behulp van de selectieknop 'beheerd/onbeheerd' kan worden gekozen of de potentiële kwaliteit van het gehele gebied of alleen van het beheerde/onbeheerde deel van het gebied wordt weergegeven.

4. Overzicht knelpunten t.a.v. potentiële kwaliteit: in deze figuur is te zien welk van de vier kritische factoren (drooglegging, openheid, verstoring, productiviteit) de grootste problemen opleveren ten aanzien van de basiskwaliteit van het gebied.

5. Verdeling beheer over potentiële kwaliteit: deze figuur geeft weer of de beheerpakketten op de juiste locaties liggen. De binnenste ring geeft de potentiële kwaliteit van het gebied in klassen weer (en komt dus overeen met figuur 3). De buitenste ring geeft weer hoeveel hectare beheer er is gelegen op/binnen iedere kwaliteitscategorie. Daarmee kan deze figuur antwoord geven op de volgende vragen:

- Ligt het zware beheer op de correcte locaties (gebieden met een hoge/redelijke 'potentiële kwaliteit') of is het gelegen op locaties die eigenlijk minder geschikt zijn (locaties met een zeer lage/lage potentiële kwaliteit)?

- Zijn er gemiste kansen (locaties die een hoge/redelijke potentiële kwaliteit hebben waarop geen/licht beheer wordt uitgevoerd)?

6. Gerealiseerde kwaliteit: de gerealiseerde kwaliteit is de combinatie van de basiskwaliteit en het toegewezen beheer. Een hoge potentiële kwaliteit resulteert niet altijd in een hoge gerealiseerde kwaliteit. Uitsluitend wanneer de juiste (zware) beheerpakketten aan locaties met een hoge potentiële kwaliteit worden toegeschreven, wordt een hoge gerealiseerde kwaliteit bereikt (het beheer is uiteindelijk de bepalende factor). Binnen deze cirkeldiagram is weergegeven hoeveel hectare van het deelgebied behoort tot de vier kwaliteitscategorieën. Met behulp van de selectieknop 'beheerd/onbeheerd' kan worden gekozen of de gerealiseerde kwaliteit van het gehele gebied of alleen van het beheerde/onbeheerde deel van het gebied wordt weergegeven.

7. Aanbod kuikengrasland: in onderstaande figuren is voor de grutto, kievit, scholekster en tureluur weergegeven hoeveel foerageerhabitat er beschikbaar is voor de kuikens. De kleuren corresponderen met de hoeveelheid hectare die beschikbaarheid is als foerageerhabitat voor een van de weidevogelgezinnen in kwestie. De grootte van de 'taartpunt' geeft weer hoeveel paar er binnen iedere categorie vallen (weergegeven in de labels is het aantal paar in de betreffende categorie. Een optimale situatie bevat zo veel mogelijk paren in de hoogste categorie ( $>1 \mathrm{ha}$ ). Bij het berekenen van de hoeveelheid hectare per weidevogelgezin is rekening gehouden met de verschillende waardes van beheerpakketten als foerageerhabitat voor weidevogelkuikens (als voorbeeld: het beheerpakket 'legselbescherming' heeft geen betekenis als foerageerhabitat voor weidevogelkuikens, in tegenstelling tot de beheerpakketten die een uitgestelde maaidatum bevatten).

\section{Status kentallen}

Tot op heden is vooral gewerkt aan de inhoudelijke invulling van de kentallenanalyse. Daarnaast is verkend op welke wijze het mogelijk is om deze analyse in te bouwen in de BoM-systematiek, zodat de kentallenanalyse met één druk op de knop kan worden uitgevoerd voor een deelgebied naar keuze en kan worden gedownload in de vorm van een Excelbestand. Het Excelbestand is op dusdanige wijze vormgegeven dat automatisch de figuren worden aangemaakt. De volgende stap in de automatisering van de kentallenanalyse is het toevoegen van een aantal scripts, die ervoor zorgen dat de data worden weggeschreven in de juiste cellen, zodat de figuren in Excel automatisch worden gegenereerd. 


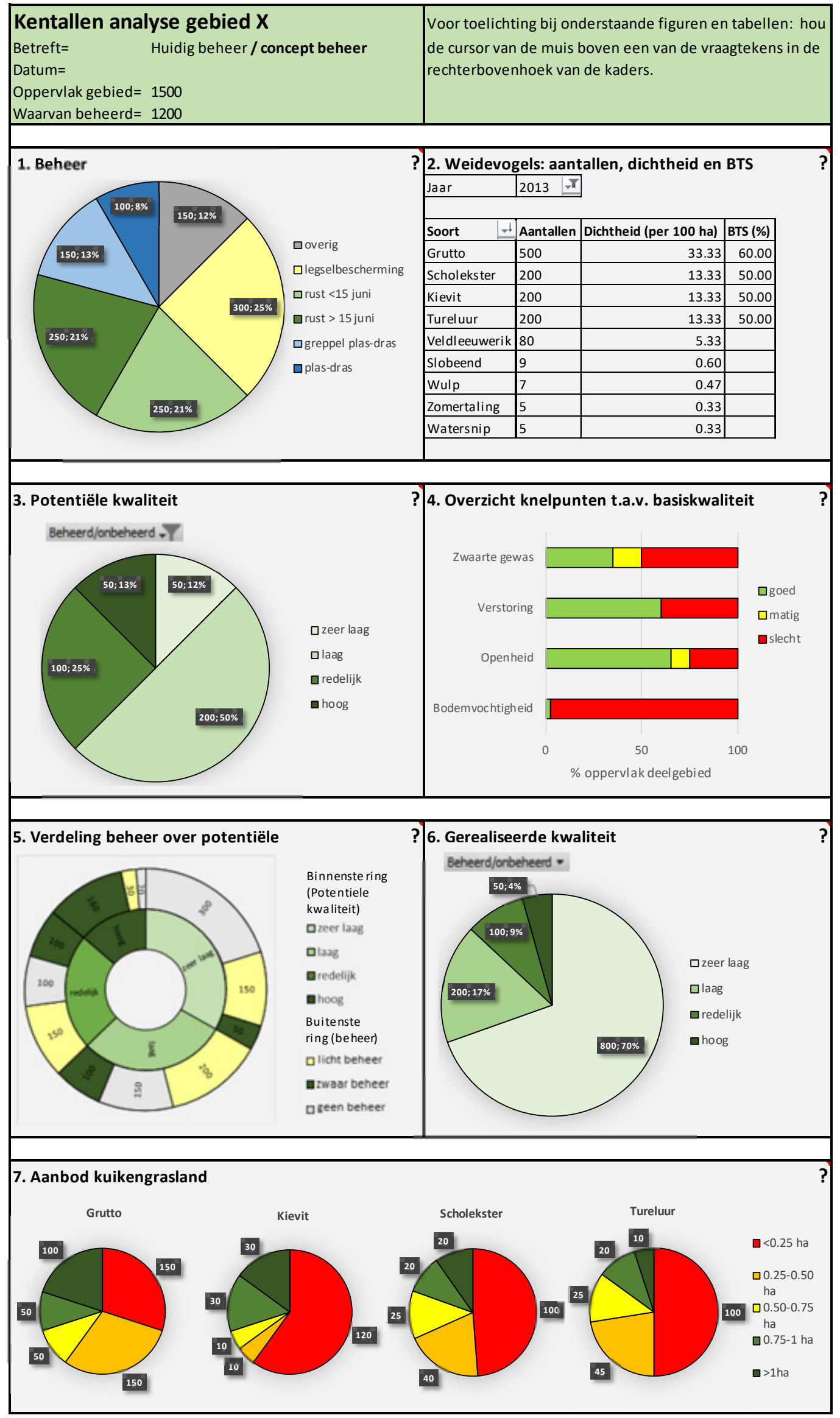

Figuur 1 Concept kentallenanalyse. Voor toelichting: zie bovenstaande tekst. 


\section{Gebruiksvriendelijkheid}

Naar aanleiding van de wensen uit 2017 en 2018 is de gebruiksvriendelijkheid van het systeem verbeterd. Hiertoe zijn de volgende aanpassingen gedaan:

- Het gehele principe van inloggen is herzien: ieder collectief heeft nu een eigen account. Aan deze accounts zijn permissies gekoppeld om bepaalde data (territoriastippen/beheer) in te zien. Dit i.v.m. de privacygevoeligheid van deze gegevens.

- Laadscherm toegevoegd bij berekenen van gerealiseerde kwaliteit: er verschijnt nu een popupscherm dat aangeeft dat de berekening wordt uitgevoerd.

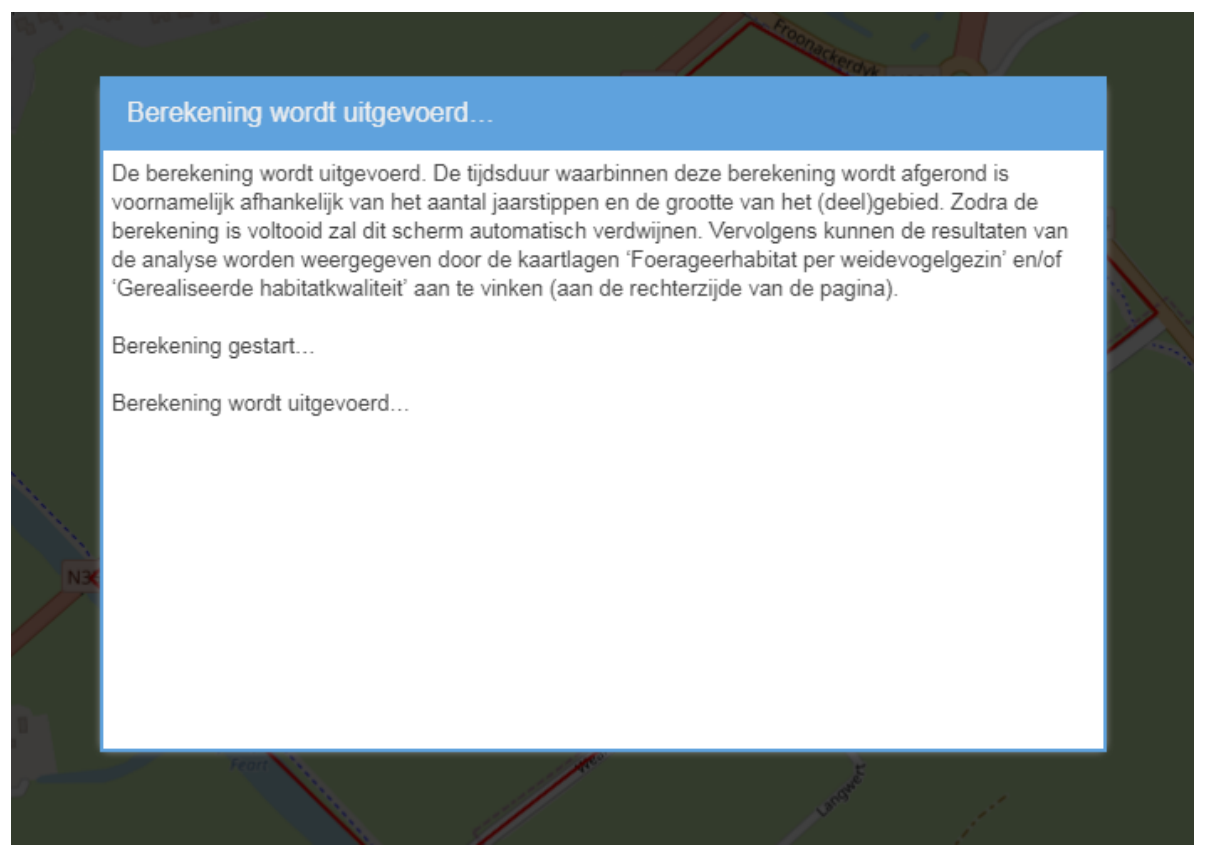

- Info pagina: Er is een infopagina aangemaakt. Op deze pagina vindt de gebruiker de benodigde contactgegevens bij hulpvragen en informatie over de ontwikkeling van het kennissysteem en de betrokken partijen.

\section{Beheer op Maat Dageningen BoM}

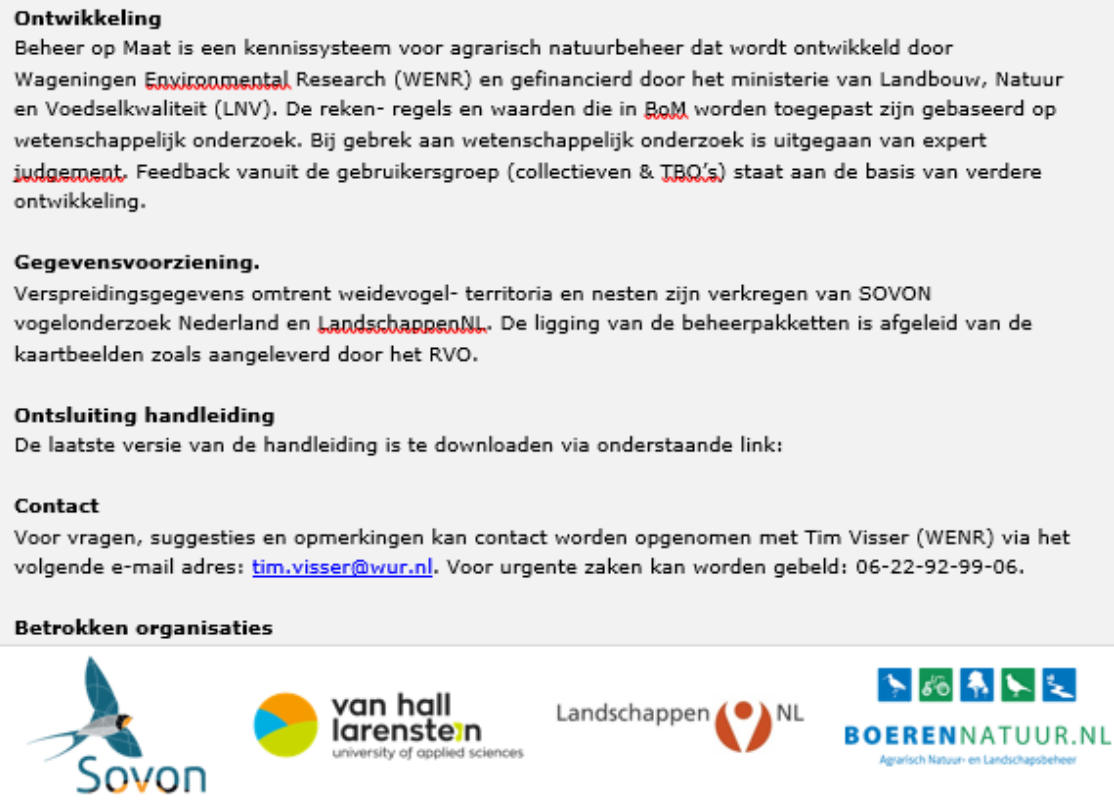


- Onderscheid inhoudelijke- en achtergrond kaartlagen vereenvoudigd: Met behulp van scheidingslijnen is onderscheid gemaakt tussen achtergrond-kaartlagen (grenzen deelgebieden / werkgebieden, luchtfoto) en inhoudelijke kaartlagen.

\section{Bekijk op kaart}

Kaart

(i) Actuele luchtfoto

(i) Collectieven

(i) Deelgebieden

(i)

(i) Reservaten

(i) Potentiele kwaliteit grutto

(i) Beheerkaart (gebruikt bij het rekenen)

- Op deze pagina zijn alle kaarten beschikbaar die binnen de analysestappen aan bod zijn gekomen. Met behulp van de kaartenbak kan de gebruiker alle kaartlagen met elkaar combineren, waardoor het verband tussen verschillende kaartlagen kan worden bekeken. De volgende kaartlagen zijn in de kaartenbak beschikbaar:

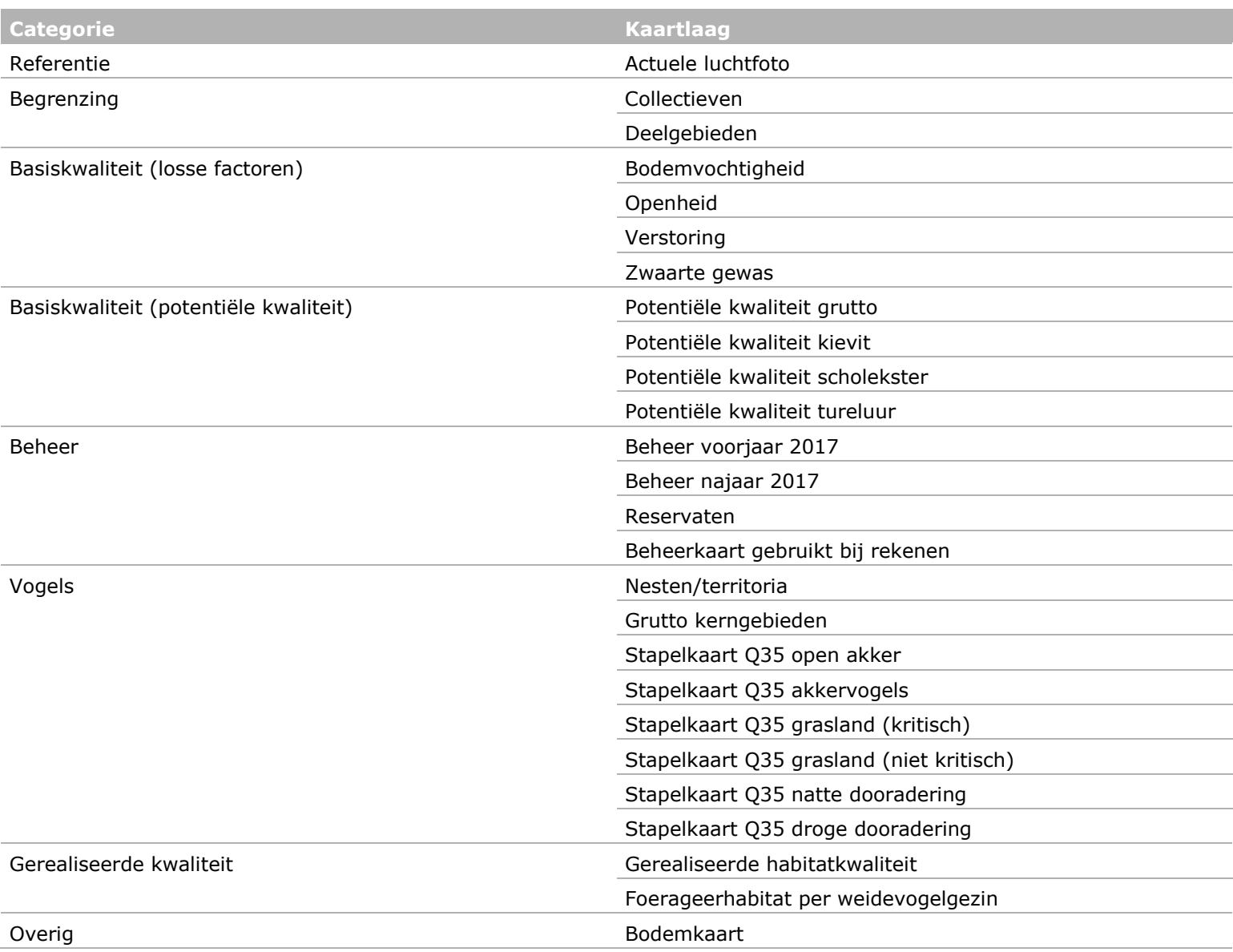




\section{Transparantie/inzichtelijkheid}

De transparantie van het kennissysteem is verbeterd door alle rekenwaarden en -regels (inclusief bijbehorende onderbouwing + literatuurverwijzingen) te ontsluiten in de vernieuwde handleiding (zie bijlage 1). Er is speciaal aandacht besteed aan de onderbouwing van de weegwaarden van de beheerpakketten. Zie hiervoor bijlage 1 van bijlage 1 .

\section{Aansluiting terminologie BoM met de regeling}

De indeling van de beheerpakketten is vernieuwd. De vernieuwde indeling sluit beter aan op de terminologie zoals die wordt gebruikt binnen de ANLb-systematiek. Daarnaast zijn sommige ANLbbeheerpakketten samengevoegd/gesplitst, omdat dit vanuit ecologisch oogpunt relevant is (voorbeeld: greppel plas-dras met uitgestelde maaidatum tot 1 mei is van marginale waarde als opgroeihabitat voor weidevogelkuikens, in tegenstelling tot greppel plas-draspercelen met een uitgestelde maaidatum tot 15 juni. In dit geval is het relevant om beide ANLb-beheerpakketten in te delen in een andere beheercategorie, waardoor verschillende weegwaarden kunnen worden toegekend. De vernieuwde indeling van de beheerpakketten (inclusief verantwoording voor de gekozen weegwaarden) is opgenomen als bijlage in de handleiding (zie bijlage 1 van bijlage 1 ).

\section{Experimenteermogelijkheden}

Een wens die tijdens de werkplaatsen van 2017 en 2018 frequent naar voren kwam, was de mogelijkheid om te experimenteren met Beheer-op-Maat (factoren manipuleren en zodoende een doorkijkje te krijgen wat dit voor weidevogels zou kunnen betekenen). Hier is invulling aan gegeven door:

1) Het mogelijk te maken om te analyseren hoe de potentiële kwaliteit van een gebied verandert wanneer er maatregelen worden genomen om deze te verbeteren (vernatten, verwijderen bomenrijen etc.). Op de webpagina kan dit worden gedaan door bij het berekenen van de gerealiseerde kwaliteit voor een of meerdere factoren de optie 'fictief optimaliseren' aan te vinken (zie rode cirkel in onderstaande figuur). Wanneer deze wordt aangevinkt, wordt het betreffende knelpunt voor het gehele deelgebied fictief opgelost. Dit zal vervolgens doorwerken op de gerealiseerde kwaliteit en daarmee op de analyse met betrekking tot de beschikbaarheid van foerageerhabitat voor weidevogelgezinnen.

2) Het mogelijk te maken om een conceptbeheermozaïek in te tekenen en te berekenen tot welke gerealiseerde kwaliteit het voorgenomen beheermozaïek zou leiden. Het aanpassen van het beheer werkt als volgt:

Binnen Beheer-op-Maat zijn twee typen gebiedslagen beschikbaar ('edit' en 'niet editable'). Beide tonen de ligging van het beheer. Het verschil tussen beide lagen zit ' $m$ in de mogelijkheid om het beheer 'experimenteel' aan te passen. Het beheermozaïek in de 'niet editable' gebiedslaag is vergrendeld en kan niet worden gewijzigd. Dit in tegenstelling tot het beheermozaïek in de 'edit gebiedslaag', waar het beheer wel kan worden gewijzigd (op perceelniveau kunnen beheerpakketten worden toegeschreven/gewijzigd). Op deze manier is het mogelijk om 'concept beheerplannen' te analyseren: Wat zou het opleveren als we het beheermozaïek op wijze X zouden veranderen...? Het beheer kan op relatief eenvoudige wijze worden aangepast. Werkwijze:

[1] Navigeer naar de pagina 'beheer' (bovenzijde pagina).

[2] Selecteer bij gebied (linkerzijde pagina) de 'edit' versie van het gebied.

[3] Selecteer aan de linkerzijde van de pagina een beheerpakket.

[4] Klik het perceel aan waarvan het beheer moet worden gewijzigd.

De gemaakte veranderingen hoeven niet handmatig te worden opgeslagen. Door de 'edit gebiedslaag' te gebruiken bij de analyse van de gerealiseerde kwaliteit (hoofdstuk 5 van bijlage 1), kan men analyseren wat het beheer in potentie oplevert. 


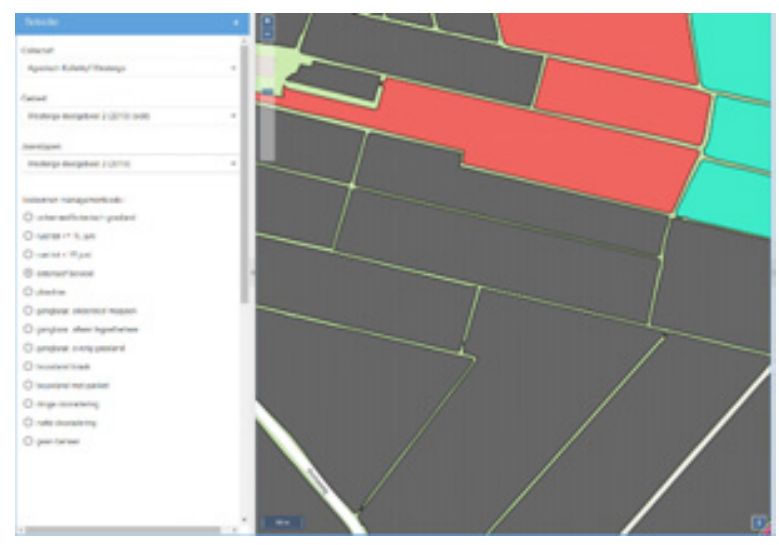

Stap 3 Selecteer het beheerpakket aan de linkerzijde van de pagina (in dit geval: extensief beweid).

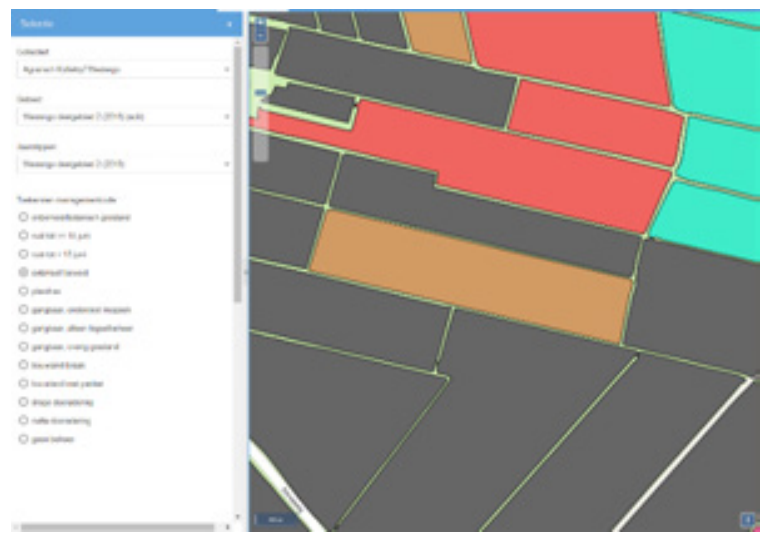

Stap 4 Perceel is aangeklikt, beheerpakket (en bijbehorende kleur) zijn gewijzigd. Wijzigingen worden automatisch opgeslagen.

\section{Validatie Beheer-op-Maat}

Een van de bevindingen uit de werkplaatsen van 2017 en 2018 is dat het essentieel is om te valideren of de habitatkwaliteit van gebieden zoals voorspeld door BoM in voldoende mate overeenkomt met de werkelijkheid.

Een goede proxymaat voor de gebiedskwaliteit is de actuele dichtheid en de ontwikkelingstrend van weidevogels, waarbij een door BoM voorspelde hoge habitatkwaliteit gepaard zou moeten gaan met hoge dichtheden en een positieve trend van de aantallen weidevogels. In 2016 is een bescheiden begin gemaakt met de validatie van BoM in de Ronde Hoep (Melman et al., 2017b), welke suggereerde dat BoM ten minste voor dit gebied realistische inzichten genereert. Deze validatie is beperkt van opzet geweest (alleen dichtheden, geen trend) en heeft op slechts één gebied betrekking. Met een breder opgezette en in meerdere gebieden uitgevoerde validatie van BoM wordt duidelijk in welke mate de kwaliteit van gebieden zoals voorspeld door BoM overeenkomt met de werkelijkheid. Daarmee wordt duidelijk of en op welk niveau de uitkomsten van BoM kunnen worden toegepast in de praktijk (planoptimalisatie, aanwijzen kerngebieden etc.) en waar ruimte is om het model te verbeteren. Een conceptonderzoeksvoorstel voor de validatie van Beheer-op-Maat is toegevoegd aan dit rapport (zie bijlage 3 ).

\section{Contact/communicatie OG, projectomgeving}

In 2018 is uitgebreid gecommuniceerd met de gebruikersgroep en betrokken partijen. In januari 2018 hebben de werkplaatsen plaatsgevonden, waarbij negentien collectieven (vertegenwoordigd door \pm zestig leden) aanwezig zijn geweest. Daarnaast is gecommuniceerd met een groot aantal gebruikers die zelf aan de slag zijn gegaan met Beheer-op-Maat. Deze gebruikers hebben Beheer-op-Maat toegepast voor hun eigen werkgebied in het kader van planoptimalisatie en zijn geholpen door ondersteuning te bieden bij het interpreteren van de resultaten en het uploaden van beheer- en territoriagegevens. Ten slotte is uitgebreid gecommuniceerd met betrokken en geïnteresseerde partijen (Staatsbosbeheer, Natuurmonumenten, Vogelbescherming, Boerennatuur etc.), meestal naar aanleiding van een presentatie. Onderstaande tabel (tabel 1) geeft een overzicht van alle relevante communicatie met de gebruikersgroep en de projectgroep van Beheer-op-Maat. 
Tabel 1 Overzicht communicatie met gebruikersgroep en projectomgeving.

\begin{tabular}{|c|c|c|c|}
\hline Organisatie & Contactpersoon & Maand & Inhoud gesprek \\
\hline Collectieven & $\begin{array}{l}19 \text { Collectieven, +/- } 45 \text { leden } \\
\text { (zie bijlage } 2 \text { voor volledige } \\
\text { lijst met namen van } \\
\text { collectieven en } \\
\text { vertegenwoordigers). }\end{array}$ & Januari & $\begin{array}{l}\text { Presentatie en instructie tijdens Werkplaatsen. Zie } \\
\text { bijlage } 2 \text { voor het verslag. }\end{array}$ \\
\hline Collectieven & 7 collectieven & Mei - oktober & $\begin{array}{l}\text { Technisch-inhoudelijke ondersteuning bij gebruik van } \\
\text { Beheer-op-Maat ten behoeve van planoptimalisatie. } \\
\text { Werkzaamheden omvatten uploaden van gegevens } \\
\text { en hulp bij interpretatie van de resultaten. }\end{array}$ \\
\hline Vogelbescherming & Celine Roodhart & Januari & $\begin{array}{l}\text { Aanwezig bij werkplaatsen. Enthousiast over } \\
\text { mogelijke toepassingen van Beheer-op-Maat. Later } \\
\text { ook mailcontact over invulling kentallenanalyse. }\end{array}$ \\
\hline Gemeente Breda & $\begin{array}{l}\text { Merlijn Hoftijzer, Wouter } \\
\text { Schuitema }\end{array}$ & Maart & $\begin{array}{l}\text { Ondersteuning m.b.v. Beheer-op-Maat bij inrichting } \\
\text { tweetal weidevogelgebieden in gemeente Breda. }\end{array}$ \\
\hline Natuurmonumenten & Johan Presscher & Maart & $\begin{array}{l}\text { Overleg over toepassing en ontwikkeling van } \\
\text { Beheer-op-Maat voor enkele gebieden van } \\
\text { Natuurmonumenten. }\end{array}$ \\
\hline Staatsbosbeheer & Jeroen van Vliet & Maart & $\begin{array}{l}\text { Overleg over toepassing en ontwikkeling van } \\
\text { Beheer-op-Maat voor enkele gebieden van } \\
\text { Staatsbosbeheer. }\end{array}$ \\
\hline Boerennatuur.nl & Wouter Rozendaal & Februari & $\begin{array}{l}\text { Advisering rol Beheer-op-Maat binnen proces van } \\
\text { planoptimalisatie van ANLb-beheerplannen. }\end{array}$ \\
\hline Boerennatuur.nl & Inger Wilms & Juni & Aansluiting van Beheer-op-Maat op SCAN-GIS. \\
\hline Boerennatuur.nl & Willemien Geertsema & Mei & Aansluiting van Beheer-op-Maat op SCAN-GIS. \\
\hline $\begin{array}{l}\text { Universiteit van } \\
\text { Utrecht }\end{array}$ & $\begin{array}{l}\text { Studenten: Bokma, C.E., } \\
\text { Havermans, S.A.C., Meijer, } \\
\text { M.J.J., van Tol, J.L.D. en } \\
\text { Visser, C.S. }\end{array}$ & Maart & $\begin{array}{l}\text { Toepassing BoM voor project van studenten in } \\
\text { opdracht van Flevo-landschap. Beheeradvies } \\
\text { weidevogelgebieden in Flevoland, mede op basis van } \\
\text { BoM-analyses. }\end{array}$ \\
\hline $\mathrm{ZHL}$ & $\begin{array}{l}\text { Ninouk Vermeer, Jasper Ohm } \\
(\mathrm{ZHL})\end{array}$ & Januari & $\begin{array}{l}\text { Advisering mogelijk gebruik BoM in } \\
\text { natuurplanvorming in Krimpenerwaard. }\end{array}$ \\
\hline $\begin{array}{l}\text { Krimpenerwaard, } \\
\text { DAT }\end{array}$ & Rob Ligtenberg, & Mei & $\begin{array}{l}\text { Advisering Deskundigen Advies Team } \\
\text { Krimpenerwaard rond planvorming natuur met } \\
\text { behulp van BoM. }\end{array}$ \\
\hline $\begin{array}{l}\text { Deskundigenteam } \\
\text { Cultuurlandschap }\end{array}$ & DT-cultuurlandschap & Maart & $\begin{array}{l}\text { Presentatie Beheer-op-Maat. Vraag aan } \\
\text { deskundigenteam: Waar ligt de waarde van dit } \\
\text { systeem + hoe dit verder te ontwikkelen? Resultaat } \\
=\text { waarde ligt in vertaalslag van wetenschappelijke } \\
\text { noties naar voor de praktijk hanteerbare info. }\end{array}$ \\
\hline Ecologica & Jaarsymposium in Evoluon & Maart & Presentatie Beheer-op-Maat. \\
\hline BoerenNatuur & Willemien Geertsema & April & Workshops BoM tijdens collectievendag. \\
\hline $\begin{array}{l}\text { Provinciale } \\
\text { ambtenaren }\end{array}$ & - & Januari & $\begin{array}{l}\text { Presentatie bij kennisdag over agrarisch } \\
\text { natuurbeheer voor provinciale ambtenaren } \\
\text { georganiseerd door Vogelbescherming Nederland. }\end{array}$ \\
\hline $\begin{array}{l}\text { Werkgroep weide- } \\
\text { en akkervogels }\end{array}$ & $\begin{array}{l}\text { Ovv Wendy Ates. Deelnemers } \\
\text { uit weidevogelprovincies }\end{array}$ & $\begin{array}{l}\text { Januari/ } \\
\text { februari }\end{array}$ & $\begin{array}{l}\text { Advisering aan de werkgroep weide- en akkervogels } \\
\text { rond de praktische vertaling van de uitkomsten van } \\
\text { het scenario onderzoek weidevogels. }\end{array}$ \\
\hline Aequator & Susan van der Salm & Juli & $\begin{array}{l}\text { Advisering gebruik BoM. Contact naar aanleiding van } \\
\text { presentatie over Beheer-op-Maat. Vraag: welke } \\
\text { factoren beïnvloeden de habitatkwaliteit voor } \\
\text { weidevogels. }\end{array}$ \\
\hline Ecosensys & Bob Jongepoerink & Mei & $\begin{array}{l}\text { Advisering gebruik BoM. Voert analyses uit m.b.v. } \\
\text { BoM in opdracht van collectief It Lege Midden. } \\
\text { Ondersteuning in de vorm van aanleveren account } \\
\text { en klaarzetten gegevens. }\end{array}$ \\
\hline $\begin{array}{l}\text { Steunpunt Agrarisch } \\
\text { Natuurbeheer }\end{array}$ & Dave Dirks & Mei & $\begin{array}{l}\text { Advisering gebruik BoM. Voert analyses uit m.b.v. } \\
\text { BoM in opdracht van ANV Hollands Noorden. } \\
\text { Ondersteuning in de vorm van aanleveren account } \\
\text { en klaarzetten gegevens. }\end{array}$ \\
\hline
\end{tabular}




\begin{tabular}{|c|c|c|c|}
\hline Organisatie & Contactpersoon & Maand & Inhoud gesprek \\
\hline $\begin{array}{l}\text { Collectieven en } \\
\text { betrokkenen } \\
\text { (LandschappenNL, } \\
\text { Vogelbescherming, } \\
\text { etc.) }\end{array}$ & Nieuwsbrief Beheer-op-Maat & September & $\begin{array}{l}\text { In september is een nieuwsbrief verstuurd over } \\
\text { Beheer-op-Maat aan alle gebruikers en betrokkenen } \\
\text { (zie bijlage 4). }\end{array}$ \\
\hline
\end{tabular}




\section{2}

In 2018 is een aantal additionele werkzaamheden verricht. Hierbij gaat het veelal om werkzaamheden die aansluiten op wensen vanuit de praktijk of om het oplossen van artefacten/bugs.

\section{Bodemkaart}

$\mathrm{Er}$ is een bodemkaart toegevoegd aan het kennissysteem. Het gaat hierbij om een bodemkaart met een vereenvoudigde classificering, waarbij onderscheid wordt gemaakt tussen de volgende bodemtypen: klei, klei op veen, leem, veen, zand.

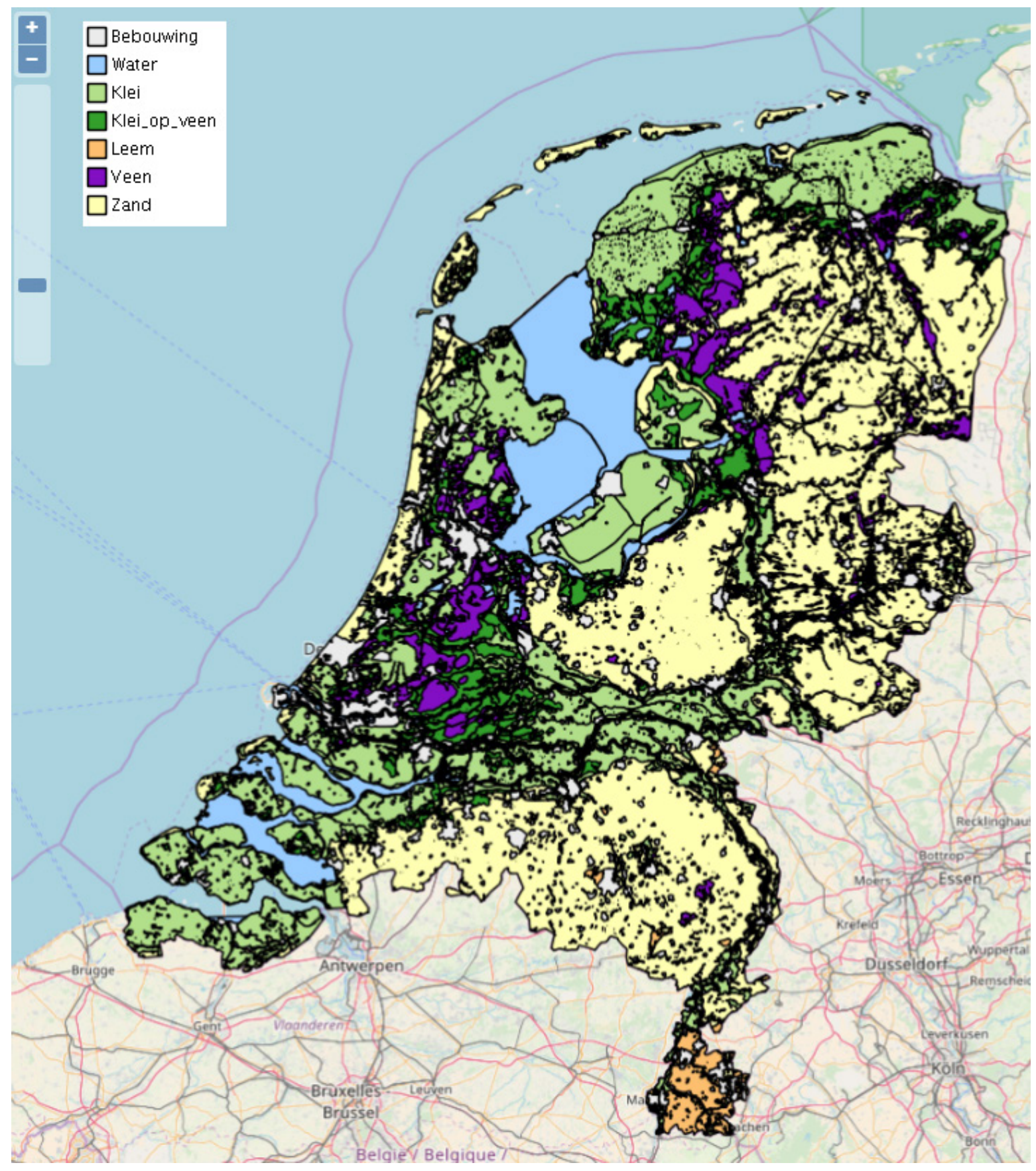

\section{Verbeteren kaart bodemvochtigheid}

In 2018 is de bodemvochtigheidskaart verfijnd. Tot op heden werd gebruikgemaakt van een droogleggingskaart die het product is van de vergelijking van het peilbesluit en de maaiveldhoogte. Binnen de vernieuwde bodemvochtigheidskaart wordt ook rekening gehouden met kwel en het bodemtype. 
De vernieuwde bodemvochtigheidskaart wordt als volgt berekend:

1. Berekenen drooglegging: de drooglegging is berekend door de maaiveldhoogte (op basis van het Algemeen Hoogtebestand Nederland) te vergelijken met het vigerende peilbesluit. Hierbij is gebruikgemaakt van het waterpeil in de winter, omdat uit onderzoek in Noord-Holland is gebleken (Schotman et al., 2008) dat de drooglegging in de winter een belangrijke relatie heeft met de trend van weidevogels en het voorkomen van natte en vochtige graslanden tijdens het broedseizoen.

2. Vertalen van de drooglegging in centimeters naar klasse-indeling bodemvochtigheid, rekening houdend met het bodemtype: het bodemtype is van grote invloed op de relatie tussen de drooglegging en de bodemvochtigheid. Zo leidt een drooglegging van $35 \mathrm{~cm}$ op veengrond tot een redelijk vochtige bodem, terwijl een drooglegging van $35 \mathrm{~cm}$ op zandgrond leidt tot een relatief droge bodem. Om deze reden is bij het vertalen van de feitelijke drooglegging (in centimeters) naar de klasse-indeling van de bodemvochtigheid (nat, vochtig, droog) rekening gehouden met het bodemtype. Dit is gedaan door de klassegrenzen per bodemtype te differentiëren (zie onderstaande tabel). De klassegrenzen en differentiatie per bodemtype zijn gebaseerd op onderzoek van Teunissen et al. (2012). Uit dit onderzoek kan de droogleggingswaarde per bodemtype worden afgelezen, waarop $75 \%$ van de populaties een negatieve/positieve ontwikkeling kent.

\begin{tabular}{|c|c|c|}
\hline Klasse & Klasse-omschrijving & Klassegrenzen (cm t.o.v. maaiveld voor veen, zand, klei en overig) \\
\hline 1 & Nat & $\begin{array}{l}\text { Drooglegging kleiner dan } 20 \text { (veen), } 30 \text { (klei op veen), } 45 \text { (klei), } 15 \text { (zand) } \\
\text { centimeter onder maaiveld. }\end{array}$ \\
\hline 3 & Droog & $\begin{array}{l}\text { Drooglegging groter dan } 35 \text { (veen), } 50 \text { (klei op veen), } 70 \text { (klei), } 30 \text { (zand) } \\
\text { centimeter onder maaiveld. }\end{array}$ \\
\hline
\end{tabular}

3. Rekening houden met kwel en wegzijging: Het optreden van kwel en wegzijging kan de bodemvochtigheid beïnvloeden. Om deze reden is op locaties waar kwel/wegzijging optreedt de drooglegging gecorrigeerd. Voorbeeld: de drooglegging op locatie $X$ (veenbodem) is $40 \mathrm{~cm}$. Locatie $X$ wordt daarom ingedeeld in klasse 3: te droog. Echter, doordat op deze locatie zeer sterke kwel optreedt ( $>0.5 \mathrm{~mm} /$ etm), wordt de drooglegging van locatie $X$ verkleind met $10 \mathrm{~cm}$. De drooglegging is daardoor verkleind tot $30 \mathrm{~cm}$, waardoor locatie $X$ wordt heringedeeld in klasse 2: vochtig. De grootte van de correctie is gebaseerd op de relatie tussen kweldruk en het effect op de bodemvochtigheid (Jansen e.a., 2009):

- kweldruk $>0.5 \mathrm{~mm} /$ etm $(\mathrm{kwel})=-10 \mathrm{~cm}$

- kweldruk $<0.5 \mathrm{~mm}$ en $>-0.5$ (intermediair) $=-4 \mathrm{~cm}$

- kweldruk $<-0.5 \mathrm{~mm}$ (wegzijging) $=+2 \mathrm{~cm}$

\section{Bug Plas-dras}

Een bug die tijdens de werkplaatsen in januari 2018 aan het licht kwam, was dat het beheerpakket 'plas-dras' geen invloed had op de plaatselijke bodemvochtigheid. Door middel van een aantal aanpassingen in de code is dit probleem opgelost. In de huidige versie van Beheer-op-Maat wordt op percelen waaraan het beheerpakket plas-dras is toegekend, gerekend met weegwaarde 1 voor het beheer en weegwaarde 1 voor de drooglegging. Bij het berekenen van de gerealiseerde kwaliteit zal het beheerpakket plas-dras ervoor zorgen dat eventuele knelpunten rondom de drooglegging op het betreffende perceel zijn opgelost.

\section{Rekenwaarden beheerpakketten herzien o.b.v. literatuuronderzoek}

De weegwaarden van de beheerpakketten zijn herzien o.b.v. uitgebreid literatuuronderzoek (zie bijlage 1 van bijlage 1 ).

\section{Toevoegen Q35-kaarten}

Er zijn zes zogenaamde 'Q35-kaarten' toegevoegd aan het kennissysteem. Deze kaarten tonen de gebieden met de hoogste dichtheden aan doelsoorten voor de vier leefgebiedtypen (grasland, open 
akker, droge dooradering, natte dooradering). De Q35-kaarten omvatten de volgende clusters van soorten ${ }^{3}$ :

1. Open akkervogels $=$ veldleeuwerik, graspieper, gele kwikstaart

2. Akkervogels = veldleeuwerik, ringmus, patrijs, kneu, kievit, gele kwikstaart

3. Grasland (kritisch) = watersnip, grutto, slobeend, tureluur, zomertaling

4. Grasland (niet kritisch) = gele kwikstaart, graspieper, kievit, slobeend, veldleeuwerik, wulp

5. Natte dooradering = kamsalamander, heikikker, poelkikker, rugstreeppad, gevlekte witsnuitlibel, groene glazenmaker, grote vuurvlinder, watersnip, zwarte stern, slobeend, tureluur, zomertaling, noordse woelmuis, beekprik, bittervoorn, grote modderkruiper

6. Droge dooradering = grauwe klauwier, braamsluiper, gekraagde roodstaart, grote lijster, kneu, patrijs, ransuil, ringmus, spotvogel, steenuil, zomertortel, geelgors, hazelmuis, grijze grootoorvleermuis, ingekorven vleermuis, tweekleurige vleermuis

Bovengenoemde combikaarten zijn gemaakt door het combineren van een aantal losse Q35-kaarten (één kaart per soort). Q35-kaarten worden gemaakt door het kleinst mogelijke areaal te selecteren waarbinnen $35 \%$ van de landelijke populatie van een specifieke soort voorkomt. Anders gezegd: de gebieden waar de soort in kwestie in de hoogste dichtheden voorkomt ( $35 \%$ van de landelijke populatie).

Op deze combikaarten is tevens af te lezen hoeveel Q35-kaarten op een specifieke locatie over elkaar heen liggen, m.a.w. hoeveel van de soorten per gridcel voorkomen. Gebieden waar veel Q35-kaarten van een soortencluster over elkaar heen liggen, zijn dus voor meerdere soorten belangrijk.

\section{Kaart met weidevogelvakken}

Tijdens de werkplaatsen is door de deelnemers meerdere malen gevraagd om meer deelgebieden en bijbehorende beheer- en weidevogelgegevens beschikbaar te maken. Dergelijke gebieden vormen de ruimtelijke eenheden waarvoor een analyse wordt uitgevoerd. Het landsdekkend handmatig intekenen van deelgebieden is onbegonnen werk. Wanneer collectieven zelf dergelijke gebieden intekenen, worden veelal praktische grenzen aangehouden (telgebieden, administratieve eenheden) en leidt dit vanuit het oogpunt van weidevogelecologie - veelal tot ongelukkige gebiedsgrenzen. Om deze reden is ervoor gekozen om een systematiek van zogenaamde weidevogelvakken te ontwikkelen.

Een weidevogelvak is een gebied dat voor weidevogelgezinnen als een ruimtelijke eenheid fungeert, omdat het gebied wordt omgrensd door onneembare barrières voor weidevogelgezinnen, zoals snelwegen, steden en brede vaarten. In andere woorden: weidevogelgezinnen zitten tijdens het broedseizoen 'opgesloten' in weidevogelvakken. Juist om deze reden is het zeer relevant de effectiviteit van het weidevogelbeheer te analyseren op het niveau van weidevogelvakken: de aanwezige weidevogelgezinnen moeten hun jongen zien groot te brengen in het foerageerhabitat dat beschikbaar is binnen de grenzen van het weidevogelvak.

In 2018 is een poging gedaan om te komen tot weidevogelvakken. GIS-technisch ziet het resultaat er redelijk uit. Verdere uitwerking is echter nodig, vooral met betrekking tot het samenvoegen en splitten van te kleine en grote gebieden.

3 Disclaimer: In de clusters ontbreekt een aantal soorten; bijvoorbeeld grauwe kiekendief in 'Q35 combikaart open akker' en kemphaan in 'Q35 combikaart grasland kritisch'. Deze (en andere) soorten ontbreken in de clusters, omdat zij vanwege hun zeldzaamheid niet geschikt zijn voor de Q35-methodiek. 


\section{$4 \quad$ Discussie}

Achterliggend doel van het project is om de bruikbaarheid van het kennissysteem voor lerend beheer in het agrarisch natuurbeheer te vergroten. De door HVHL georganiseerde werkplaatsen in januari en februari 2017/18 vormden een zeer rijke bron aan gebruikerservaringen en verbeterwensen. Daarnaast is het kennissysteem en de benadering die daaraan ten grondslag ligt ook voor andere gelegenheden en in andere gremia gebruikt en ook die contacten leverde input op voor verdere verbeteringen. Hier gaan we kort op in.

\section{Gebruik Beheer-op-Maat}

Gebruik collectieven (werkplaatsen 2018)

Tijdens de werkplaatsen, waar negentien collectieven aan deelnamen, werd duidelijk dat de collectieven het werken met Beheer-op-Maat als zinvol ervaren: ze kunnen nu op een geobjectiveerde manier kijken naar de basiskwaliteit en de gerealiseerde beheerkwaliteit in hun gebieden (Manhoudt et al., 2018; zie bijlage 2). Het kennissysteem brengt concreet in beeld waar verbeteringen in beheer wenselijk zijn en/of bevestigt dat de collectieven het beheer op orde hebben.

In veel gevallen werden de knelpunten in habitatkwaliteit die BoM in beeld bracht door het collectief in grote lijnen herkend ${ }^{4}$. Door gebruik van het kennissysteem werden deze knelpunten concreet getoond en daarmee bespreekbaar. Het ging bij de bespreking om zaken als de omvang en ernst van de knelpunten de oorzaak ervan. Voorts welke verbeteringen zouden kunnen worden doorgevoerd om deze knelpunten weg te nemen. Omdat BoM gebieden volgens eenduidige rekenregels en criteria analyseert, is de output goed te doorzien (één taal, één begrippenset) en kunnen bovendien gebieden met elkaar worden vergeleken. Hierdoor ontstonden als vanzelf discussies tussen de collectieven over de verschillen en overeenkomsten tussen gebieden, met vragen als: is drooglegging bij jullie ook het grootste probleem? Op welke wijze sluiten jullie aan op reservaatbeheer? Hebben jullie ook te maken met een beperkte openheid?

De collectieven zien het kennissysteem als een praktisch hanteerbare leidraad om hen te helpen het beheer verder te verbeteren. De collectieven gaven aan het kennissysteem te kunnen gebruiken voor verschillende doeleinden bij het weidevogelbeheer:

- Het plannen van het beheer;

- Evaluatie van het jaarlijkse beheer;

- Het verbeteren van het lastminutebeheer;

- Het invullen en uitwerken van het beheer in compensatiegebieden;

- Onderbouwen van noodzakelijke wijzigingen in beheer per deelnemer of per gebied;

- Verantwoorden aan derden, zoals provincies en vrijwilligersorganisaties en aan gebiedspartijen, zoals de terreinbeherende organisaties.

De werkplaatsen in 2018 hebben bereikt dat de collectieven positief zijn over Beheer-op-Maat en ermee verder willen. Het feit dat veel verbeteringen zijn doorgevoerd op basis van de suggesties die tijdens de werkplaatsen van 2017 zijn aangedragen, heeft hier in belangrijke mate aan bijgedragen ("Jullie hebben er veel aan gedaan, BoM ziet er een stuk beter uit."). Ook tijdens de werkplaatsen van 2018 zijn door de collectieven veel suggesties voor verdere verbetering aangeleverd. Deze hebben zowel betrekking op het kennissysteem als op de organisatie van de ontsluiting van de benodigde gegevens.

\footnotetext{
${ }^{4}$ Dat neemt niet weg dat ook werd geconstateerd dat info in sommige gevallen niet actueel is en/of dat de gehanteerde klasse-indeling vrij grof is.
} 
Gebruik collectieven (Buiten werkplaatsen)

Het gebruik van Beheer-op-Maat is in 2018 fors toegenomen. Naast het gebruik tijdens de

werkplaatsen zijn meerdere collectieven in eigen tijd aan de slag gegaan met Beheer-op-Maat, veelal in het kader van de planoptimalisatie zoals die begin 2018 van start is gegaan.

\section{Gebruik als communicatiemiddel bij planoptimalisatie}

In het kader van werkzaamheden van het Kennisteam Weidevogels Zuid-Holland zijn werkbezoeken gebracht aan de collectieven agrarisch natuurbeheer van de Krimpenerwaard en Alblasserwaard. Bij het bespreken van het gebied als geheel is gebruikgemaakt van BoM-analyses die voor onderdelen van de gebieden is uitgevoerd. Dergelijke overzichten blijken goed bruikbaar om de bespreking van het gebied (sterke punten en verbeterpunten) te structureren. Daarbij leren beide partijen: enerzijds geeft BoM een mooi overzicht, dat ook voor collectieven welkom is. Anderzijds kunnen collectieven de vinger leggen op onvolkomenheden in BoM (missende gegevens, gebrek aan actualiteit), wat voor BoM-makers welkom is om tot verbetering van het kennissysteem te komen.

\section{Gebruik door TBO's}

Ook binnen de terreinbeherende organisaties lijkt de interesse in het kennissysteem toe te nemen. In opdracht van ZHL is een analyse uitgevoerd van de weidevogelkwaliteiten en belangrijkste knelpunten in de Krimpenerwaard (zie bijlage 5). Door Natuurmonumenten en Staatsbosbeheer is meermaals interesse getoond in de analyses die BoM te bieden heeft.

\section{Leermomenten m.b.t. gebruik van Beheer-op-Maat:}

- De werkplaatsen hebben laten zien dat BoM in beginsel een waardevolle tool kan zijn voor lerend beheer. Nu zijn de werkplaatsen in 2017 en 2018 een min of meer incidenteel gebeuren geweest; voor lerend beheer zouden dergelijke sessies regelmatig moeten plaatsvinden. In welke vorm dat zou moeten en met welke urgentie, is een punt van nadere overweging. Het zou goed zijn als daaraan naast collectieven ook terreinbeheerders, onderzoekers en beleidsmakers deel zouden nemen. Daarmee komt er een meer gedeeld beeld over wat er nodig en mogelijk is om tot een effectief weidevogelbeheer te komen.

- Of de collectieven BoM daadwerkelijk zullen gaan gebruiken, hangt af van (1) stimulans vanuit provincies om onderbouwde beheerplannen op te stellen; (2) gebruikersvriendelijkheid van BoM en (3) validatie van BoM, waaruit blijkt dat de inzichten die BoM oplevert betrouwbaar en voldoende nauwkeurig zijn. Om dit te bereiken, doen we de volgende aanbevelingen/suggesties:

- Interactie gebruikers-ontwikkelaars essentieel; evt. instellen van vaste gebruikersgroep onder regie van BoerenNatuur?

- Technisch-inhoudelijke helpdesk instellen;

- Lijst van veelgestelde vragen bijhouden;

- Validatie BoM ter hand nemen;

- Prikkel vanuit overheden om tot optimale beheerplannen te komen is essentieel.

\section{Actualiteit en betrouwbaarheid van de gegevens; organisatie}

Uit de gebruikerservaringen komt naar voren dat de bruikbaarheid en relevantie van BoM sterk worden bepaald door de actualiteit en de betrouwbaarheid van de gegevens. Bij het gebruik van BoM zal er dus voor zorg gedragen moeten worden dat deze zaken op orde zijn. De verantwoordelijkheid hiervoor moet worden benoemd en bij een organisatie worden gelegd. Het ligt voor de hand BoerenNatuur hier een centrale rol te geven. Dat geldt zowel voor de gegevens voor de potentiële habitatkwaliteit (ontwatering, openheid, verstoring, zwaarte van het gewas), voor de gerealiseerde kwaliteit (het beheer) als voor de aanwezigheid en BTS (Bruto Territoriaal Succes) van weidevogelgezinnen. Voor weidevogels is al eerder een voorstel gedaan om te komen tot een zogenaamd Weidevogel Informatie Portaal (WIP) (Teunissen et al., 2014).

In 2018 is een eerste poging gedaan om de uitwisseling van bovengenoemde gegevens beter te laten verlopen. BoerenNatuur is beheerder van het SCAN-GIS-portaal, dat door collectieven wordt gebruikt om beheergegevens in te zien. Hierdoor beschikt BoerenNatuur over alle benodigde beheergegevens. In het gesprek met BoerenNatuur is duidelijk geworden dat BoerenNatuur bereid is de aansluiting van BoM op SCAN-GIS mogelijk te maken, zeker gezien de forse toename in het aantal gebruikers. BoerenNatuur heeft aangegeven dat zij het aanleveren van beheergegevens op zich zullen nemen. Daarbij werd vermeld dat de gegevens - in verband met de nieuwe Europese privacywetgeving - 
uitsluitend worden afgegeven in samenspraak met de betreffende collectieven. Hiertoe is een bericht geplaatst op het intranet van SCAN-GIS, met het verzoek toestemming af te geven als men aan de slag wil met Beheer-op-Maat. Het doel is om dit proces in 2019 verder te verkennen: welke mogelijkheden zijn er om de ontsluiting van gegevens volledig automatisch te laten verlopen? Met welke frequentie is dit mogelijk? etc.

Wat betreft de territoriagegevens heeft BoerenNatuur aangegeven geen eigenaar van de gegevens te zijn. De gegevens zijn in eigendom van de collectieven en LandschappenNL. Een overleg tussen gegevens leverende organisaties (Sovon, BFVW), collectieven, LandschappenNL, provincies/BIJ12 zou tot een modus kunnen leiden hoe gegevens voor dit doel zouden kunnen worden aangewend. BoerenNatuur heeft zich bereid verklaard hierin te willen bemiddelen.

\section{Aandacht voor validatie}

Met de forse toename in het gebruik groeit de urgentie om de uitkomsten van het model te valideren: Wat is de nauwkeurigheid en de betrouwbaarheid van de uitkomsten? In welke omstandigheden gelden ze? In 2018 is veel aandacht besteed aan het beschrijven van de huidige kennisbasis en onderbouwing van het kennissysteem. Deze is uitgeschreven in de handleiding, waarmee gelijktijdig de transparantie van het kennissysteem is verbeterd (bijlage 1).

De volgende stap is het valideren van de uitkomsten van Beheer-op-Maat: in hoeverre komen de uitkomsten voor de toereikendheid van het habitataanbod overeen met de situatie in het veld? Een eerste aanzet voor validatie is uitgevoerd (Melman et al., 2017b), een diepgaander onderzoek is zeer gewenst. De collectieven gaven dat tijdens de werkbijeenkomsten ook aan. In 2018 is hiervoor voorbereidend werk verricht in de vorm van een onderzoeksvoorstel (bijlage 3). Voor het uitvoeren van dergelijk onderzoek zijn zo veel mogelijk gegevens met betrekking tot weidevogelterritoria en het BTS wenselijk. Verschillende collectieven hebben zich uit eigen beweging bereid verklaard hiervoor gegevens aan te willen leveren. Dit zou op landelijk niveau moeten worden afgetast.

\section{Verbreding van BoM naar andere leefgebiedtypen}

Op meerdere fronten wordt gevraagd naar verbreding van BoM naar de overige leefgebiedtypen (droge dooradering, natte dooradering, open akkers). Het gaat hier niet alleen om collectieven die zich voornamelijk richten op andere doelsoorten dan weidevogels, maar ook om het PBL, om beleidsadviezen te kunnen geven, zowel wat betreft potenties voor natuur buiten NNN als wat betreft de te verwachten effecten van agrarisch natuurbeheer. Het is duidelijk dat veel werk zal moeten worden verricht om BoM operationeel te maken voor deze leefgebiedtypen. Het is belangrijk om hierbij alle kansen te grijpen en om inspanningen op dit front zo veel mogelijk te bundelen.

\section{Status BoM}

BoM is stap voor stap ontwikkeld, als instrument om meer grip te krijgen op de kwaliteit van de plannen in het agrarisch natuurbeheer. Getracht is daarbij alle relevante wetenschappelijke kennis te benutten en om een breed draagvlak te krijgen bij alle betrokkenen van het agrarisch natuurbeheer. De verschillende rapporten die al die jaren zijn uitgebracht, geven aan dat dat een zoektocht is geweest. De fase waarin het agrarisch natuurbeheer zich nu bevindt, die van toenemende professionalisering van de collectieven en toenemende maatschappelijke druk om tot een effectievere beheerpraktijk te komen, maken dat BoM meer en meer als instrument voor lerend beheer herkend en erkend wordt.

In 2018 is Beheer-op-Maat aanzienlijk verbeterd, zowel inhoudelijk (kentallenanalyse, weidevogelvakken, bodemkaarten, kaartenbak, verfijnen en onderbouwen rekenregels, speelmogelijkheden, updaten kaartbeelden) als op het vlak van de gebruiksvriendelijkheid (laadscherm, ontsluiting handleiding, verbeteren inloggen etc.). Ook het gebruik is in 2018 fors toegenomen. Doel is om het gebruik van Beheer-op-Maat in 2019 nog meer te stimuleren, vooral in de vorm van lerend beheren. Wellicht kan een andere vorm van werkplaatsbijeenkomsten hier een belangrijke rol in spelen. De werkplaatsen in 2017 en 2018 stonden vooral in het teken van kennismaken met het systeem. In 2019 kan wellicht worden ingezet op een werkvorm die het vergelijken van onderlinge resultaten aan de hand van de analysemogelijkheden in Beheer-op-Maat stimuleert (benchmarking).

Verder is het belangrijk om vanwege de forse toename in het gebruik door te pakken en het systeem verder te ontwikkelen aan de hand van de verbeterpunten die tijdens de werkplaatsen zijn aangedragen. Het verbeteren van de uitwisseling van gegevens en validatie van de uitkomsten vormen hier een belangrijk onderdeel van. 


\section{Conclusies en aanbevelingen}

Beheer-op-Maat ontsluit wetenschappelijke kennis met betrekking tot weidevogelbeheer op een laagdrempelige manier. Door het kennissysteem in te zetten voor eigen werkgebied kunnen de gebruikers werken aan planoptimalisatie. De betekenis van BoM zit 'm met name in de context van lerend beheer en benchmarking. Het gebruik van één taal en één begrippenset en de topografiegebonden ontsluiting van kennis zijn daarbij belangrijke dragers.

Het kennissysteem voor Agrarisch Natuurbeheer, Beheer-op-Maat (BoM), is op een aantal punten aangepast aan wensen van gebruikers (beheercollectieven). De belangrijkste inhoudelijke verbeteringen omvatten een verfijning van de bodemvochtigheidskaart, herziening van de weegwaarden voor de beheerpakketten o.b.v. literatuuronderzoek, uitbreiding van de speelmogelijkheden en toevoeging van een bodemkaart. De gebruikersvriendelijkheid van het systeem is verbeterd door laadschermen toe te voegen, de handleiding te ontsluiten en het proces van inloggen te vereenvoudigen. Daarnaast is veel voorbereidend werk verricht. Zo is een concept ontwikkeld voor een kentallenanalyse - waarin de belangrijkste kentallen omtrent de effectiviteit van weidevogelbeheer overzichtelijk worden weergegeven - en is een samenwerking gestart met BoerenNatuur en LandschappenNL, met als doel de gegevensvoorziening te verbeteren.

De doorgevoerde verbeteringen hebben tot veel enthousiasme geleid. Mede daardoor is het aantal gebruikers fors toegenomen. Met de forse toename van het aantal gebruikers groeit de noodzaak om het kennissysteem te valideren. Daarnaast zijn er belangrijke opgaven voor het kennissysteem, waaronder het stimuleren van het gebruik voor lerend beheer en een uitbreiding naar de overige leefgebiedtypen. Ten slotte vormt het optimaliseren van de gegevensvoorziening een belangrijke opgave, omdat een gebrek aan gegevens de bruikbaarheid van Beheer-op-Maat in de weg kan staan.

\section{Aanbevelingen:}

- Oprichten gebruikersgroep. Het afgelopen jaar is duidelijk geworden dat verbeteringen aan het kennissysteem naar aanleiding van verbeterwensen van gebruikers tot veel enthousiasme leiden. Om verbeterwensen in de toekomst op een meer systematisch manier in beeld te krijgen, lijkt het verstandig om een gebruikersgroep samen te stellen, die met enige regelmaat bijeenkomt om de ontwikkeling van het kennissysteem te bespreken. De verbeterwensen die binnen deze gebruikersgroep naar voren komen, zouden sturend kunnen zijn voor doorontwikkeling van het kennissysteem.

- Technische-inhoudelijke helpdesk instellen. Het afgelopen jaar is een helpdesk opgericht waar gebruikers van Beheer-op-Maat terecht kunnen met vragen. Van deze helpdesk is veelvuldig gebruikgemaakt (vragen vanuit zeven collectieven en diverse andere organisaties). Er is zowel geholpen bij het inladen van gegevens als bij het interpreten van de resultaten. Gezien de optimalisatieronde die in juni 2019 zijn beslag krijgt, lijkt het verstandig om een dergelijke helpdesk nogmaals beschikbaar te stellen, zodat hulp kan worden geboden bij het gebruik van Beheer-opMaat.

- Ontsluiting gegevens. De beperkte beschikbaarheid van beheer- en territoriagegevens staat het gebruik van Beheer-op-Maat soms in de weg. Het is raadzaam om de samenwerking met gegevensbeherende organisaties zoals LandschappenNL en Boerennatuur verder te ontwikkelen, zodat Beheer-op-Maat met regelmaat wordt gevoed met up-to-date gegevens.

- Valideren \& kalibreren. Met de forse toename in het gebruik groeit de urgentie om de uitkomsten van het model te valideren: wat is de nauwkeurigheid en de betrouwbaarheid van de uitkomsten? In welke omstandigheden gelden ze? Validatie van het kennissysteem zal tevens de mogelijkheid bieden om de rekenregels en -waarden te kalibreren. 
- Inhoudelijk doorontwikkelen. Het model kan inhoudelijk verder worden ontwikkeld. Het afgelopen jaar is duidelijk geworden dat er veel interesse is in de kentallenanalyse. Het zou raadzaam zijn om het mogelijk te maken deze analyse met één druk op de knop uit te kunnen voeren voor een werkgebied naar keuze. Verder liggen er mogelijkheden om de rekenregels te verfijnen aan de hand van nieuwe wetenschappelijke inzichten en/of naar aanleiding van de validatie/kalibratie van het kennissysteem.

- Lerend beheer. De werkplaatsen hebben laten zien dat BoM in beginsel een waardevolle tool kan zijn voor lerend beheer. Nu zijn de werkplaatsen in 2017 en 2018 een min of meer incidenteel gebeuren geweest; voor lerend beheer zouden dergelijke sessies regelmatig moeten plaatsvinden. In welke vorm dat zou moeten en met welke urgentie is een punt van nadere overweging. Het zou goed zijn als, naast collectieven, ook terreinbeheerders, onderzoekers en beleidsmakers deel zouden nemen. Daarmee komt er een meer gedeeld beeld over wat er nodig en mogelijk is om tot een effectief weidevogelbeheer te komen. Wellicht vormt de te ontwikkelen kentallenanalyse een aanknopingspunt om in 2019 een bijeenkomst te organiseren die zich voornamelijk richt op lerend beheren.

- Uitbreiden leefgebiedtypen. Op meerdere fronten wordt gevraagd naar verbreding van BoM naar de overige leefgebiedtypen (droge dooradering, natte dooradering, open akkers). Het gaat hier niet alleen om collectieven die zich voornamelijk richten op andere doelsoorten dan weidevogels, maar ook om het PBL, om beleidsadviezen te kunnen geven, zowel wat betreft potenties voor natuur buiten NNN als wat betreft de te verwachten effecten van agrarisch natuurbeheer. Het is duidelijk dat veel werk zal moeten worden verricht om BoM operationeel te maken voor deze leefgebiedtypen. Het is belangrijk om hierbij alle kansen te grijpen en om inspanningen op dit front zo veel mogelijk te bundelen. 


\section{Literatuur}

Onderstaande tabel geeft een overzicht van de belangrijkste rapporten omtrent de ontwikkeling van het kennissysteem Beheer-op-Maat. Alle rapporten zijn te downloaden door de link uit de kolom 'download' te kopiëren in de adresbalk van een webbrowser.

$\begin{array}{ll}\text { Jaar } & \text { Referaat } \\ \text { a } & \text { Melman, Th.C.P., M.H.C. van Adrichem, M.H.C., M.E.A. Broekmeyer, J. Clement, R. Jochem, } \\ & \text { H.A.M. Meeuwsen, F.G.W.A. Ottburg, A.G.M. Schotman, T. Visser, 2017. Natuurcombinaties } \\ & \text { en Europese natuurdoelen : ontwikkeling van een methode om natuurdoelen te realiseren } \\ & \text { buiten het Natuurnetwerk Nederland. WOt-technical report } 107 \text { (ISSN 2352-2739). } \\ & \text { Wageningen. }\end{array}$

2017 Melman, Th.C.O, A.G.M. Schotman, B. Vanmeulebrouk, I. Staritsky, H.A.M. Meeuwsen,

b 2017. Kennissysteem agrarisch natuurbeheer: aandacht voor inpasbaarheid en validatie. Wageningen, Wageningen Environmental Research, Rapport 2791. 66 blz.; 32 fig.; 1 tab; 16 ref.

2017 Melman, Th.C.P. \& H. Sierdsema, 2017. Weidevogelscenario's: Mogelijkheden voor aanpak c van verbetering van de weidevogelstand in Nederland. Wageningen, Wageningen Environmental Research, Rapport 2796. 30 blz.; 3 fig.; 12 tab.; 18 ref.

2015 A.G.M. Schotman, Th.C.P. Melman, J.H. Ringrose, H.A.M. Meeuwsen, B. Vanmeulebrouk, W. Nieuwenhuizen, 2015. Beheer-op-Maat, op weg naar lerend beheer voor weidevogels. Wageningen, Alterra Wageningen UR (University \& Research Center), Alterra-rapport. 40 blz.; 23 fig.; 6 tab.; 21 ref.

2014 Th.C.P. Melman, H. Sierdsema, R. Buij, G. Roerink, H. ten Holt, S. Martens, H.A.M. Meeuwsen, A.G.M Schotman, 2014, Uitwerking kerngebieden weidevogels; -peiling draagvlak bij provincies; -verbreding kennissysteem BoM. Wageningen, Alterra Wageningen UR (University \& Research centre), Alterra-rapport 2564, 84 blz.; 16 fig.; 21 tab.; 49 ref.

2013 Sierdsema, H., A.G.M. Schotman, E.B. Oosterveld en Th.C.P. Melman, 2013. Weidevogelkerngebieden Noord-Holland; vergelijking van vier scenario's. Wageningen, Alterra, Alterra-rapport 2435; Sovon-rapport 2013/23; A\&W-rapport 1899. 75 blz.; 21 fig.; 19 tab.; 44 ref.

2012 Teunissen, W.A., A.G.M. Schotman, L.W. Bruinzeel, H. ten Holt, E.O. Oosterveld, H. H. Sierdsema, E. Wymenga en Th.C.P. Melman, 2012. Op naar kerngebieden voor weidevogels in Nederland. Werkdocument met randvoorwaarden en handreiking. Wageningen, Alterra, Alterra-rapport 2344. Nijmegen, Sovon Vogelonderzoek Nederland, Sovon-rapport 2012/21, Feanwâlden, Altenburg \& Wymenga ecologisch onderzoek, A\&W- rapport 1799. 144 blz.; 63 fig.; 22tab.; 76 ref.

2011 Meeuwsen, H.A.M. \& R. Jochem (2011). Openheid van het landschap; Berekeningen met het model Viewscape. Wageningen, Wettelijke Onderzoekstaken Natuur \& Milieu, WOtwerkdocument 281. 74 blz. 31 fig.; 5 tab.; 8 ref.; 4 bijl.

2011 Bruinzeel, L.W. \& A.G.M. Schotman 2011. Onderbouwing verstoringsafstanden weidevogels Fryslân. A\&W rapport.1624/Alterra 2184 Altenburg \& Wymenga ecologisch onderzoek, Feanwâlden/Alterra Wageningen

2009 Kleijn, D., Lamers, L. P. M., van Kats, R. J. M., Roelofs, J. G. M., \& van 't Veer, R. (2009). Ecologische randvoorwaarden voor weidevogelsoorten in het broedseizoen: resultaten van een pilotstudie in het Wormer-en Jisperveld (No. 2009/dk113). Directie Kennis, Ministerie van Landbouw, Natuur en Voedselkwaliteit.

2009 Melman, Dick, Michiel Kiers, Henk Meeuwsen, Alex Schotman, Henk Sierdsema, Bas Vanmeulebrouk, Popko Wiersma, 2009. Werkzaamheden weidevogelonderzoek BO-2008; voortgangsrapportage Beheer-op-maat 2008: naar identificatie kerngebieden weidevogelbeheer. Wageningen, Alterra, Alterra-rapport 1865. 116 blz. 19 fig.; 24tab.; 38 ref.; 13 kaarten.

2009 Jansen, P. C., Hendriks, R. F. A., \& Kwakernaak, C. (2009). Behoud van veenbodems door ander peilbeheer: maatregelen voor een robuuste inrichting van het westelijk veenweidegebied (No. 2009). Alterra.

\section{Download}

http://edepot.wur.nl/

431944

http://edepot.wur.nl/ 408667

http://library.wur.nl/ WebQuery/wurpubs/f ulltext/417827 http://edepot.wur.nl/ 344835 http://edepot.wur.nl/ 317059 http://edepot.wur.nl/ 260929 http://library.wur.nl/ WebQuery/wurpubs/f ulltext/240248

http://library.wur.nl/ WebQuery/edepot/42 221 http://edepot.wur.nl/ 240248 http://library.wur.nl/ WebQuery/wurpubs/w ever/379748 http://edepot.wur.nl/ 8137 https://library.wur.nl/ WebQuery/wurpubs/r eports/392891 
2008 Schotman, A.G.M, Th.C.P. Melman, S.R. Hensen, M.A. Kiers, H.A.M. Meeuwsen,

http://edepot.wur.nl/ O.R. Roosenschoon \& B. Vanmeulebrouk, 2008. Het grutto-mozaïekmodel als kwaliteitstoets 3870 weidevogelbeheer; ontwikkelingen en toepassingen 2004-2008. Wageningen, Alterra, Alterra-rapport 1408. 64 blz.; 12 fig.; 9 tab.; 44 ref.

2008 Van 't Veer, R., Sierdsema, H., Musters, C.J.M., Groen, N. \& Teunissen, W. 2008 b. Weidevogels op landschapsschaal, ruimtelijke en temporele veranderingen Ministerie van Landbouw, Natuur en Voedselkwaliteit; Directie Kennis Ede.

2007 Kleijn, D., Dimmers, W., van Kats, R., Melman, D. \& Schekkerman, H. 2007. De voedselsituatie voor gruttokuikens bij agrarisch mozaïekbeheer. Wageningen, Alterra, Alterra-rapport 1487. 50 blz.; 10 fig.; 6 tab.; 31 ref.

http://library.wur.nl/ WebQuery/wurpubs/f ulltext/240248 http://library.wur.nl/ WebQuery/wurpubs/f ulltext/42221

2007 Schotman, A.G.M., M.A. Kiers \& Th.C.P. Melman, 2007. Onderbouwing gruttogeschiktheidskaart; Ten behoeve van Grutto mozaïekmodel en voor identificatie van http://library.wur.nl/ weidevogelgebieden in Nederland. Wageningen, Alterra, Alterra-rapport 1407. 47 blz.; 7 fig.; 221\%20(2007 8 tab.; 25 ref.

2006 A.G.M. Schotman, Th.C.P. Melman, 2006. Haalbaarheidsstudie nieuw weidevogelgebied. Wageningen, Alterra, Alterra-Rapport 1336. 48 blz.; 10 foto's; 7 tab.; 21 ref. Foto's Kees Scharringa. 518

2005 Schotman, A.G.M., Th.C.P. Melman, H.A.M. Meeuwsen, M.A Kiers \& H. Kuipers, 2005. Naar een Grutto-mozaïekmodel; Definitie van een model voor evaluatie vooraf van de effectiviteit http://edepot.wur.nl/ van mozaïekbeheer. Stand van zaken juni 2005. Wageningen, Alterra, Alterra-rapport 1199. 57 blz.; 2 fig.; 5 tab; 23 ref.

Onderstaande bronnen zijn gebruikt bij het bepalen van de rekenregels en rekenwaarden in Beheerop-Maat:

(1) E. B., Terwan, P., Guldemond, J. A., \& Paassen, A. G. (2007). Mozaïekbeheer voor weidevogels: evaluatie en mogelijkheden voor optimalisering. Ministerie van Landbouw, Natuur en Voedselkwaliteit, Directie Kennis.

(2) Boerennatuur.nl. (2017). Overzicht beheerpakketten Agrarisch Natuur- \& Landschapsbeheer, versie 1.6 (Beheerjaar 2017)

(3) Deru, J., Eekeren, N. V., \& Lenssinck, F. Mest voor weidevogelgebieden in veenweiden: dikke fractie gescheiden drijfmest is alternatief voor ruige mest. $V$-focus: vakblad voor adviseurs in de dierlijke sector, 28-30.

(4) van Eekeren, N., Bommelé, L., Bloem, J., Schouten, T., Rutgers, M., de Goede, R., ... \& Brussaard, L. (2008). Soil biological quality after 36 years of ley-arable cropping, permanent grassland and permanent arable cropping. applied soil ecology, 40(3), 432-446.

(5) Kleijn, D., Berendse, F., Verhulst, J., Roodbergen, M., Klok, T. C., \& van 't Veer, R. (2008). Ruimtelijke dynamiek van weidevogelpopulaties in relatie tot de kwaliteit van de broedhabitat. Welke factoren beïnvloeden de vestiging van weidevogels? (No. 1579). Directie Kennis, Ministerie van Landbouw, Natuur en Voedselkwaliteit.

(6) Schekkerman, H., \& Beintema, A. J. (2007). Abundance of invertebrates and foraging success of Black-tailed Godwit Limosa limosa chicks in relation to agricultural grassland management. Ardea, 95(1), 39-54.

(7) Kleijn, D., Dimmers, W. J., van Kats, R. J. M., Melman, T. C. P., \& Schekkerman, H. (2007). De voedselsituatie voor gruttokuikens bij agrarisch mozaïekbeheer (No. 1487). Alterra.

(8) Visser, T., Melman, D., Buij, R., \& Schotman, A. (2017). Greppel plas-dras voor weidevogels: betekenis als habitatonderdeel voor weidevogelkuikens (No. 2845). Wageningen Environmental Research.

(9) Kruk, M., Noordervliet, M. A. W., \& Ter Keurs, W. J. (1997). Survival of black-tailed godwit chicks Limosa limosa in intensively exploited grassland areas in The Netherlands. Biological Conservation, 80(2), 127-133.

(10) Oosterveld, E.B. (MS). Habitat use by Black-tailed Godwit chicks Limosa limosa with agricultural mosaic management in Fryslân (The Netherlands), with special reference to grazing and herb richness. Manuscript.

(11) Nijland, F. (2007). Resultaten Innovatieve monitoring 2005-2007. Weidevogelmeetnet Friesland, Leeuwarden.

(12) Terwan, P., Oosterveld, E.B., de Ruiter, H. \& Guldemond, J.A. (2003). Beheersmozaïeken voor de Grutto. Opzet van de experimenten met optimaal Gruttobeheer in zes gebieden in Noord- en West- 
Nederland in het kader van het project 'Nederland- Gruttoland'. Paul Terwan onderzoek \& advies, Utrecht, Altenburg \& Wymenga ecologisch onderzoek, Veenwouden/CLM Onderzoek en Advies, Utrecht.

(13) Schekkerman, H., \& Müskens, G. J. D. M. (2000). Produceren Grutto's Limosa limosa in agrarisch grasland voldoende jongen voor een duurzame populatie. Limosa, 73, 121-134.

(14) Schekkerman, H., Teunissen, W., \& Oosterveld, E. (2009). Mortality of Black-tailed Godwit Limosa limosa and Northern Lapwing Vanellus vanellus chicks in wet grasslands: influence of predation and agriculture. Journal of Ornithology, 150(1), 133.

(15) Kruk, M., Noordervliet, M. A. W., \& Ter Keurs, W. J. (1997). Survival of black-tailed godwit chicks Limosa limosa in intensively exploited grassland areas in The Netherlands. Biological Conservation, 80(2), 127-133.

(16) Nijland, F. (2007). Resultaten Innovatieve monitoring 2005-2007. Weidevogelmeetnet Friesland, Leeuwarden.

(17) Buker, J. B., \& Winkelman, J. E. (1987). Eerste resultaten van een onderzoek naar de broedbiologie en het terreingebruik van de grutto in relatie tot het graslandbeheer. Directie Beheer Landbouwgronden.

(18) Schekkerman, H. (1997). Graslandbeheer en groeimogelijkheden voor weidevogelkuikens (No. 292). DLO-Instituut voor Bos-en Natuuronderzoek.

(19) Sikkema, M. \& van Lierop, S. (2007). De functie van onbemeste graslandranden voor weidevogels in de broedtijd. Studentenverslag Hogeschool Van Hall/Larenstein, Velp.

(20) Green, R. E. (1986). The management of lowland wet grassland for breeding waders. Chief Scientist's Directorate, N 626. Nature Conservancy Council, Peterborough.

(21) Galbraith, H. (1988). Effects of agriculture on the breeding ecology of lapwings Vanellus vanellus. Journal of applied ecology, 487-503.

(22) Blomqvist, D., \& JOHANSSON, O. C. (1995). Trade-offs in nest site selection in coastal populations of Lapwings Vanellus vanellus. Ibis, 137(4), 550-558.

(23) Redfern, C.P.F. (1982) Lapwing nest sites and chick mobility in relation to habitat. Bird Study, 29, 201-208.

(24) Schekkerman, H., Teunissen, W., \& Oosterveld, E. (2005). Broedsucces van grutto's bij agrarisch mozaïekbeheer in" Nederland gruttoland" (No. 1291). Alterra

(25) Huijsmans, J. F. M., Schröder, J. J., Vermeulen, G. D., De Goede, R. G. M., Kleijn, D., \& Teunissen, W. A. (2008). Emissiearme mesttoediening: ammoniakemissie, mestbenutting en nevenaspecten. B.V. Wageningen.

(26) Oosterveld, E. B., Kleijn, D., \& Schekkerman, H. (2008). Ecologische kenmerken van weidevogeljongen en de invloed van beheer op overleving. Kennisoverzicht en effectiviteit van maatregelen (No. 2008/090). Directie Kennis, Ministerie van Landbouw, Natuur en Voedselkwaliteit (27) Teunissen, W., Willems, F., \& Majoor, F. (2007). Broedsucces van de Grutto in drie gebieden met verbeterd mozaïekbeheer. Beek-Ubbergen, The Netherlands: SOVON Vogelonderzoek Nederland.

(28) Wiersma P., H.J. Ottens, M.W. Kuiper, A. E. Schlaich, R.H.G. Klaassen, O. Vlaanderen, M. Postma \& B.J. Koks. 2014. Analyse effectiviteit van het akkervogelbeheer in provincie Groningen. Rapport Stichting Werkgroep Grauwe Kiekendief, Scheemda.

(29) Verstegen K. \& Sloothaak. 2012. Pilotproject: Maatregelen voor kievit op bouwland 2012.

'Kansen voor de kievit'. Coördinatiepunt Landschapsbeheer \& AP Natuuradvies, S.L. 


\section{Bijlagen}

Bijlage 1: Handleiding Beheer-op-Maat

(y)

bijlage 1.pdf

Bijlage 2: Verslag werkplaatsen Beheer-op-Maat januari 2018

(4)

bijlage 2.pdf

Bijlage 3: Onderzoeksvoorstel validatie Beheer-op-Maat

(y) 2

bijlage 3.pdf

Bijlage 4: Nieuwsbrief Beheer-op-Maat september 2018

(y)

bijlage 4.pdf

Bijlage 5: Reflectie Krimpenerwaard o.b.v. BoM

(f)

bijlage 5.pdf 
Wageningen Environmental Research Postbus 47

6700 AA Wageningen

T 0317480700

www.wur.nl/environmental-research

Wageningen Environmental Research

Rapport 2927

ISSN 1566-7197
De missie van Wageningen University \& Research is 'To explore the potential of nature to improve the quality of life'. Binnen Wageningen University \& Research bundelen Wageningen University en gespecialiseerde onderzoeksinstituten van Stichting Wageningen Research hun krachten om bij te dragen aan de oplossing van belangrijke vragen in het domein van gezonde voeding en leefomgeving. Met ongeveer 30 vestigingen, 5.000 medewerkers en 10.000 studenten behoort Wageningen University \& Research wereldwijd tot de aansprekende kennisinstellingen binnen haar domein. De integrale benadering van de vraagstukken en de samenwerking tussen verschillende disciplines vormen het hart van de unieke Wageningen aanpak. 



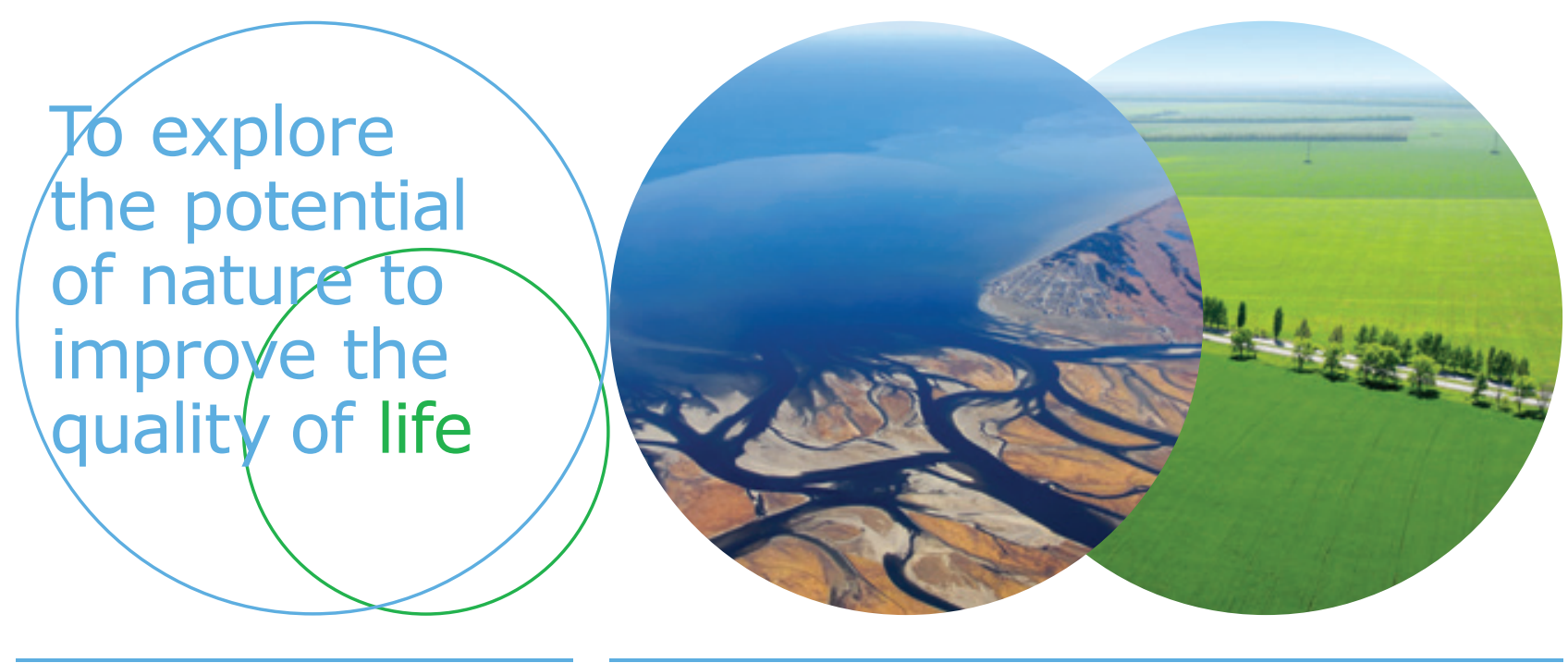

Wageningen Environmental Research Postbus 47

$6700 \mathrm{AB}$ Wageningen

T 317480700

www.wur.nl/environmental-research

Rapport 2927

ISSN 1566-7197
De missie van Wageningen University \& Research is 'To explore the potential of nature to improve the quality of life'. Binnen Wageningen University \& Research bundelen Wageningen University en gespecialiseerde onderzoeksinstituten van Stichting Wageningen Research hun krachten om bij te dragen aan de oplossing van belangrijke vragen in het domein van gezonde voeding en leefomgeving. Met ongeveer 30 vestigingen, 5.000 medewerkers en 10.000 studenten behoort Wageningen University \& Research wereldwijd tot de aansprekende kennisinstellingen binnen haar domein. De integrale benadering van de vraagstukken en de samenwerking tussen verschillende disciplines vormen het hart van de unieke Wageningen aanpak. 